\title{
Nitrification in the oligotrophic Atlantic Ocean.
}

\author{
Darren R. Clark ${ }^{1}$, Andrew P. Rees ${ }^{1}$, Charissa Ferrera ${ }^{2}$, Lisa Al-Moosawi ${ }^{1}$, Paul J. Somerfield ${ }^{1}$, \\ Carolyn Harris ${ }^{1}$, Graham D. Quartly ${ }^{1}$, Stephen Goult ${ }^{1}$, Glen Tarran ${ }^{1}$, Gennadi Lessin ${ }^{1}$.
}

${ }^{1}$ Plymouth Marine Laboratory, Prospect Place, The Hoe, PL1 3DH.

${ }^{2}$ The Marine Science Institute, Velasquez St., University of the Philippines, Diliman, Quezon City 1101 Philippines.

Correspondence to: Darren Clark (drcl@pml.ac.uk)

\begin{abstract}
The recycling of scarce nutrient resources in the sunlit open ocean is crucial to ecosystem function. Ammonium oxidation, the first stage of the nitrification process, directs ammonium derived from organic matter decomposition towards the regeneration nitrate, an important resource for photosynthetic primary producers. However, the technical challenge of making nitrification rate measurements in oligotrophic conditions combined with the remote nature of these marine systems means that data availability, and the understanding that provides, is limited. This study reports rate measurements of ammonium oxidation over a 13, $000 \mathrm{~km}$ transect within the photic zone of the Atlantic Ocean. These measurements, at relatively fine resolution (order $300 \mathrm{~km}$ ), permit the examination of interactions with environmental conditions that may warrant explicit development and inclusion in model descriptions. At all locations we report measurable rates with significant variability between and within Atlantic provinces. This adds to evidence that nitrification is an important component of pelagic nitrogen cycling which modifies the inorganic nitrogen inventory of the sunlit ocean. Particular features of interest included a significant hemispheric difference in ammonium oxidation rate and elevated rates associated with mesoscale eddy features. Statistical analysis of potential links between ammonium oxidation rate and routinely measured ecosystem variables indicated significant correlative structure,

20 explaining $\sim 65 \%$ of the data variability. Differences between sampling depths were of the same magnitude or greater than horizontally resolved differences along the transect length, identifying distinct biogeochemical niches between depth horizons. Principle component analysis demonstrated that the best overall match between ammonium oxidation rate and environmental variables involved a combination of chlorophyll-a concentration, the duration of the light phase and silicate concentration (which we argue to be a short-term tracer of physical instability). Results allude to an association between ammonium oxidation and potentially short-term product(s) of photosynthetic activity and subsequent degradation. Approximately $35 \%$ of data variability was not explained, which may include descriptions of DOM pool dynamics.
\end{abstract}

\section{Introduction}

Oligotrophic gyres and their transition regions are the largest biome on Earth, covering approximately $60 \%$ of its surface (Eppley and Peterson, 1979), and are expanding as a result of the warming climate (Polovina et al., 2008). Biogeochemical processes in these regions have the potential to influence global elemental cycles. Within the sunlit ocean, photosynthetic cells fix carbon dioxide $\left(\mathrm{CO}_{2}\right)$ and assimilate inorganic nutrients to synthesise organic molecules and build biomass (Azam et al., 1983). Either directly or indirectly, this biomass supports the ecosystem and contributes over half of global organic carbon export (Emerson et al., 2001). Persistent stratification in these systems impedes

35 nutrient inputs to the sunlit region from the deep ocean, constraining microbial growth (Eppley and Peterson, 1979, Moore et al., 2013). Consequently, efficient organic matter decomposition and inorganic nutrient regeneration are crucial to ecosystem function. Decomposition regenerates inorganic nitrogen in the form of ammonium $\left(\mathrm{NH}_{4}{ }^{+}\right)$, which rarely accumulates in the open surface-ocean as it is readily used in anabolic and chemotrophic microbial processes. Evidence demonstrates that nitrification, the 2-stage oxidation of $\mathrm{NH}_{4}{ }^{+}$via nitrite $\left(\mathrm{NO}_{2}^{-}\right)$to nitrate $\left(\mathrm{NO}_{3}{ }^{-}\right)$, takes place in

40 the photic zone of open oceans (Santoro et al., 2013) where it directly competes with photosynthetic cells for the $\mathrm{NH}_{4}{ }^{+}$ resource (Smith et al., 2014). The outcome of this competitive interaction is important; by moderating the composition and concentration of the dissolved inorganic nitrogen pool $\left(\mathrm{NH}_{4}{ }^{+}, \mathrm{NO}_{2}{ }^{-}, \mathrm{NO}_{3}{ }^{-}\right)$, nitrification influences nutrient limitation patterns for primary production at the basin scale (Partensky et al., 1999; Palinska et al., 2002; Fawcett et al., 2015; Moore et al., 2013). Biological processes within the ocean's upper mixed layer modify its chemistry and

45 subsequently influence the composition of deep water masses through particle sedimentation, decomposition and remineralisation, with global implications for productivity and climate over a range of temporal scales (Rafter et al., 
2013; Tuerena et al., 2015). In addition, nitrification is a source of the climatically active gas $\mathrm{N}_{2} \mathrm{O}$ within the surface ocean, which readily exchanges with the lower atmosphere. The yield of $\mathrm{N}_{2} \mathrm{O}$ from nitrification is the cause of greatest uncertainty in global oceanic $\mathrm{N}_{2} \mathrm{O}$ emission budgets (Santoro et al., 2011; Zamora and Oschlies, 2014). Characterising the distribution and constraints on nitrification is an important step towards fully assessing pelagic nitrogen transformations in the open ocean, although observations at the oceanic basin scale are limited (Clark et al., 2008; Shiozaki et al., 2016).

Within the open oceans, pelagic nitrification is distributed in a characteristic depth profile; low rates are measured in the well-lit near-surface waters while the highest rates are reported at, or close to, the base of the well-lit photic zone in association with the primary nitrite maximum (PNM) and the deep chlorophyll maximum (DCM); rates drop rapidly below this depth into the twilight zone of the mesopelagic (Smith et al., 2016; Newell et al., 2013). Observational data have been crucial to the development of this understanding and indicate that environmental factors act simultaneously to structure the vertical distribution of nitrifying organisms and their activity. Evidence identifies roles for light, $\mathrm{NH}_{4}{ }^{+}$ concentration, organic matter flux and competitive interactions with phytoplankton (Fawcett et al., 2015; Shiozaki et al., 2016; Olson, 1981; Smith et al., 2014; 2016; Bresseler and Boyd, 2009; Newell et al., 2011). However, the statistical analysis of nitrifying organism activity and diversity in relation to environmental factors explains only a fraction of the data variability, alluding to further complex and undefined interactions between the nitrifying activity of these organisms and their environment (Clark et al., 2014; Bouskill et al., 2012). A better appreciation of the factors that most significantly influence nitrifying activity is required to guide future fieldwork observations and ultimately, the development and explicit inclusion of such relationships in models.

Here we present relatively high-resolution photic zone measurements of the first stage of nitrification - ammonium oxidation rate $\left(\mathrm{R}_{\mathrm{NO} 2}\right)$ - across a 13,000 km oligotrophic Atlantic Ocean transect to examine the process rate distribution and potential links to environmental conditions. Investigations were conducted during the Atlantic Meridional Transect program (Rees et al., 2017), which, since 1995, has undertaken annual (or bi-annual) scientific observations of the

70 Atlantic Ocean between the UK and southern hemisphere locations including the Falkland Islands and Punta Arenas (Chile). The cruise track has historically navigated through marine provinces that include the Atlantic gyres, the equatorial upwelling convergence zone, mesotrophic fringing regions and regions influenced by eastern boundary upwelling ecosystems (Mauritania, Benguela), sampling significant variability in biological, physical and chemical conditions. By navigating between hemispheres, observations incorporate contrasting seasons, a signature that is

75 evident in biogeochemical observations, despite persistent water-column stability that typifies tropical and sub-tropical open oceans. Within this observational context, the overarching objective of the study was to highlight interactions between the rate of ammonium oxidation and environmental conditions that may warrant explicit development and inclusion in model descriptions.

\section{Methods}

\subsection{Water column characterization.}

This study was undertaken during the Atlantic Meridional Transect (AMT) cruise $19\left(13^{\text {th }}\right.$ October to $1^{\text {st }}$ December 2009) aboard the RRS James Cook between Falmouth (UK) and Punta Arenas (Chile; Fig. 1), passing through the following Atlantic provinces (Longhurst, 1998); North Atlantic Drift (NADR), North Atlantic subtropical gyre (NAST), North Atlantic tropical gyre (NATR), Western tropical Atlantic (WTRA), South Atlantic gyre (SATL). Seawater was

85 collected for biogeochemical observations from a total of 120 CTD-rosette casts, of which 33 were used for isotope studies to derive rates of ammonium oxidation. An instrumental package was deployed during solar noon to derive light depth profiles using Photosynthetically Active Radiation (PAR) data recorded by a Chelsea Instruments PAR sensor. A stainless-steel rosette unit was deployed during dawn casts (typically 06:00 GMT), incorporating a Sea-Bird 9/11 plus Conductivity, Temperature, Depth system, a Chelsea MKIII Aquatracka fluorimeter and 20 L Niskin bottles for water 90 collection from specific sampling depths.

\subsection{Nutrient analysis.}

Inorganic nutrient samples collected from dawn casts were immediately analysed. Nitrite $\left(\mathrm{NO}_{2}{ }^{-}\right)$, nitrate $\left(\mathrm{NO}_{3}{ }^{-}\right)$, phosphate $\left(\mathrm{PO}_{4}{ }^{3-}\right)$ and silicate $\left(\mathrm{Si}(\mathrm{OH})_{4}\right)$ were measured colorimetrically with a 5-channel segmented flow Bran and 
Luebbe AAIII autoanalyzer, using methods described previously (Woodward and Rees, 2001). The concentration of $\mathrm{NH}_{4}{ }^{+}$was not determined during this study.

\subsection{Analytical Flow Cytometry.}

Microbial cells were enumerated based on their light scattering and auto-fluorescence properties using a BD FACSort $^{\mathrm{TM}}$ flow cytometer. Photosynthetic cells were analysed live within 1-2 hours of collection. Non-photosynthetic cells were fixed with paraformaldehyde for 1 hour at $4{ }^{\circ} \mathrm{C}$ and then stained with SYBR Green I DNA stain (Life Technologies, Paisley, UK) in the dark at room temperature for 1 hour. Live samples were analysed at a flow rate of $180 \mu \mathrm{L} \mathrm{min}^{-1}$ for 4 minutes. Fixed/stained samples were analysed at either 50 or $12 \mu \mathrm{L} \mathrm{min}^{-1}$ for 1-2 minutes, depending on concentration. Data acquisition for photosynthetic cells was triggered on red (chlorophyll) fluorescence while the enumeration of SYBR Green I-stained bacteria and archaea was triggered on green fluorescence. Flow rates were calibrated daily using fluorospheres of known concentration.

\subsection{R $\mathrm{R}_{\mathrm{NO} 2}$ determination using ${ }^{15} \mathrm{~N}$ isotope studies.}

Approximately $4 \mathrm{~L}$ of seawater collected from depths equivalent to $14 \%, 1 \%$ and $0.1 \%$ of surface measured PAR (sPAR) was used for $\mathrm{R}_{\mathrm{NO} 2}$ studies. The isotope dilution approach (Clark et al., 2007; 2008; 2014) was used to derive the rate of ammonium oxidation, by measuring the rate of product formation $\left(\mathrm{NO}_{2}^{-}\right.$regeneration). These $4 \mathrm{~L}$ sample volumes were amended with ${ }^{15} \mathrm{NO}_{2}^{-}$at $<10 \%$ of the ambient concentration. Following amendment, triplicate $500 \mathrm{~mL}$

110 sub-samples were taken. Within these triplicate sub-samples, pre-incubation $\mathrm{NO}_{2}$ concentration and ${ }^{15} \mathrm{~N}$ enrichment was determined by synthesising Sudan-1 (see below) from sample $\mathrm{NO}_{2}{ }^{-}$. Sudan-1 is synthesised for this purpose as it is readily formed and collected at room temperature, it is stable and amenable to both purification and isotopic analysis. From the remaining volume, triplicate $500 \mathrm{~mL}$ incubation vessels were filled and placed in deck incubation units covered with neutral density filters to simulate sPAR depths according to Joint Global Ocean Flux Study protocols 115 (IOC, 1994). Incubation boxes were flushed with recirculating depth-appropriate temperature-controlled seawater. Following approximately 10 hours of day-time incubation, experiments were terminated by GF/F filtration. Sudan-1 was synthesised from $\mathrm{NO}_{2}{ }^{-}$within $500 \mathrm{~mL}$ samples, allowing post-incubation $\mathrm{NO}_{2}{ }^{-}$concentration and ${ }^{15} \mathrm{~N}$ enrichment to be measured. During these studies, a pre-incubation ${ }^{15} \mathrm{NO}_{2}{ }^{-}$enrichment of $5.41 \pm 2.18 \%$ was achieved, which was diluted by $0.92 \pm 0.83 \%$ on average due to biological activity during incubation.

120 For the synthesis of Sudan-1, the first reagent $(0.8 \mathrm{~g}$ of aniline sulphate in $200 \mathrm{~mL} 3 \mathrm{M} \mathrm{HCl})$ was added to samples in the proportion $0.5 \mathrm{~mL}$ per $100 \mathrm{~mL}$ sample volume. After mixing, samples were left for 5 minutes to homogenize, after which sample $\mathrm{pH}$ was verified to be approximately 2.0. Reagent $2(24 \mathrm{~g} \mathrm{NaOH}$ and $0.416 \mathrm{~g}$ 2-napthol in $200 \mathrm{~mL}$ Milli Q) was added in the proportion $0.5 \mathrm{~mL}$ per $100 \mathrm{~mL}$ sample volume. Samples were again mixed and left for 5 minutes before sample $\mathrm{pH}$ was verified to be approximately 8.0. The development of Sudan-1 was complete after 30 125 minutes of incubation at room temperature. Samples were acidified with citric acid (final pH 5.5) and an appropriate volume of deuterated Sudan-1 internal standard $\left(100 \mathrm{ng} \cdot \mu \mathrm{L}^{-1}\right)$ was added. Deuterated Sudan-1, which was used for sample quantification, was synthesized and purified according to methods described previously (Clark et al., 2006; 2007). Samples were collected by solid phase extraction (SPE) using octadecyl (C18) $6 \mathrm{~mL}, 500 \mathrm{mg}$ cartridges. SPE columns were stored at $-20^{\circ} \mathrm{C}$ until analysis.

130 At the land-based laboratory, samples eluted from SPE cartridges were purified by high performance liquid chromatography (HPLC). Using a ramping methanol/Milli-Q water profile in combination with a Gemini-NX 5u C18 110A $250 \times 4.6 \mathrm{~mm}$ column, sample peaks were resolved. The peak containing Sudan-1 internal standard was retained using a fraction collector while the remaining sample volume was discarded. Fraction-collected samples were dried and stored over anhydrous silica gel until further analysis.

135 Purified silylated samples were analysed by Gas Chromatography Mass Spectrometry using a HP-5ms column (30 $\mathrm{m} \times 0.25 \mathrm{~mm}$ internal diameter), with the ramping profiles and extracted ions described in Clark et al. (2007). Using $\mathrm{NO}_{2}{ }^{-}$concentration and enrichment measurements, the rate of $\mathrm{NO}_{2}{ }^{-}$dilution was determined by applying the BlackburnCaperon model (Blackburn, 1979; Caperon et al., 1979).

\subsection{Statistical analysis.}


$140 \quad \mathrm{R}_{\mathrm{NO} 2}$ rate data and associated explanatory variables were analysed using a range of multivariate statistical methods (Clarke et al., 2014). Most variables were skewed, so prior to analysis all variables except phosphate excess ( $\mathrm{P}^{*}$; calculated as $\left.\mathrm{P}^{*}=\left[\mathrm{PO}_{4}{ }^{3-}\right]-\left(\left[\mathrm{NO}_{3}{ }^{-}\right] / 16\right)\right)$ were log-transformed to reduce the influence of extreme values in subsequent analyses. Variables were normalized by subtracting the mean and dividing by the standard deviation to convert them all to a common dimensionless scale. Relationships among samples based on the explanatory variables were visualised 145 using Principal Components Analysis (PCA), and hypothesis testing for differences among groups of samples was undertaken using Analysis of Similarities (ANOSIM) with ordered factors (Somerfield et al., 2021). The generalised ANOSIM statistic is a scaled measure of effect size comparable across different tests.

To analyse relationships between $\mathrm{R}_{\mathrm{NO} 2}$ rates and explanatory variables the data for each sPAR band were analysed separately. To determine whether there was structure among variables that warranted further analysis, explanatory variables were subject to Type 2 Similarities Profiles (SIMPROF) analysis (Somerfield and Clarke, 2013). A Euclidean distance matrix was calculated for $\mathrm{R}_{\mathrm{NO} 2}$ rates. A stepwise search algorithm (BVSTEP) with forward selection and backward elimination steps (Clarke and Warwick, 1998) was used to search for the smallest subset of explanatory variables that, in combination, 'best matched' the pattern of $\mathrm{R}_{\mathrm{NO} 2}$ rates across samples, the best match being defined as maximising the rank correlation between corresponding distance matrices. The algorithm was run with 20 restarts of 6

155 randomly selected variables. The significance of the maximum rank correlation was tested using an appropriate permutation test (Clarke et al., 2008).

\subsection{Contemporaneous physical oceanography data.}

The ship, RRS James Cook made routine physical measurements whilst underway using the thermosalinograph to give temperature and salinity of the water at $\sim 5 \mathrm{~m}$ depth, and a depth profile of currents relative to the ship using the vessel-mounted $150 \mathrm{kHz}$ Acoustic Doppler Current Profiler (ADCP). The latter were corrected using the ship's navigation to give absolute instantaneous currents along the ship's track. To put these measurements in context, data were subsequently obtained from satellite altimeter and profiling floats that were in the area. These two sources of data were particularly useful in understanding anomalous observations at two of the CTD stations $\left(28^{\circ} \mathrm{S}, 39^{\circ} \mathrm{S}\right)$.

The altimetry data were sourced from Copernicus Marine Environment Monitoring Service (CMEMS) who combine the sea surface height measurements from available observations and interpolated these data on to a regular $0.25^{\circ} \mathrm{x}$ $0.25^{\circ}$ grid. Variations in sea level at the mesoscale (order 100-300 km) could be interpreted as eddies, with a local negative anomaly having cyclonic flow about it (clockwise in the southern hemisphere) and highs (anticyclones) having flow in the opposite direction. These flows were in geostrophic balance and thus represent stable current regimes, not incorporating tides or the effect of short wind bursts. Because of the long and near global altimetric record these data 170 can be used to identify regions of persistent variability and to track the evolution of features over periods ranging from weeks to years. However, satellites only give a near-surface view.

Profiles of temperature and salinity in the vicinity of the ship's track were provided by Argo floats, which are autonomous profilers typically recording 0-2000 m vertical sections every 10 days. As these instruments are freely drifting within the ocean, the location and timing of their measurements are not linked to that of the ship. Argo data for the required regions were obtained, and the profiles analysed to give a measure of the Mixed Layer Depth (MLD) as the depth at which temperature was more than $3{ }^{\circ} \mathrm{C}$ below that of the surface.

\section{Results}

\subsection{Temperature, salinity and PAR.}

Characteristic physical features of oligotrophic oceans were demonstrated (Fig. 2a, b, c). The water column was thermally stratified, with sampling locations straddling a temperature range of approximately $12-29^{\circ} \mathrm{C}$. The deepest mixed layer depths were associated with the central regions of the Atlantic gyres. Stratification weakened towards the northern and southern limits of the transect. In terms of salinity, sampling depths incorporated a range of 34.3-37.5. The most saline regions were associated with the ocean gyres and were highest in the Northern gyre. A region of relatively low salinity water was associated with the surface $30 \mathrm{~m}$ of the WTRA, defining the lower limit of the salinity range measured. In terms of the light field, $0.1 \%$ sPAR defined the deepest sampling point and equated to a depth within the range 75-200 m. Light dose (defined as the light intensity multiplied by the day-light duration) across sampling depths 
spanned $\sim 2$ orders of magnitude. Day light duration increased progressively south, associated with the seasonal transition from boreal autumn to austral spring.

\subsection{Inorganic nutrients and dissolved oxygen.}

Inorganic nutrient concentration measurements (Fig. 3) demonstrated oligotrophic $\left(<100 \mathrm{nmol} \mathrm{L}^{-1} \mathrm{NO}_{3}{ }^{-}\right.$and $\left.\mathrm{PO}_{4}{ }^{3-}\right)$ conditions throughout the transect at $14 \%$ sPAR. At the $1 \%$ sPAR depth, the concentration of $\mathrm{NO}_{3}{ }^{-}$and $\mathrm{PO}_{4}{ }^{3-}$ was generally low $\left(<600 \mathrm{nmol} \mathrm{L}^{-1}\right.$ and $<150 \mathrm{nmol} \mathrm{L}^{-1}$ respectively). The highest concentrations of $\mathrm{NO}_{3}{ }^{-}$and $\mathrm{PO}_{4}{ }^{3-}$ were measured at the $0.1 \%$ sPAR depth, notably in the NATR/WTRA/SATL region. A P* of approximately $0.2 \mu \mathrm{mol} \mathrm{L}^{-1}$ was measured at South Atlantic stations. $\mathrm{A} \mathrm{NO}_{2}{ }^{-}$concentration maximum was associated with the $1 \%$ sPAR depth

195 where an average of $117 \pm 112 \mathrm{nmol} \mathrm{L}^{-1}$ was measured. Extremely low concentrations of $\mathrm{Si}(\mathrm{OH})_{4}$ were measured in the well-lit surface ocean, progressively increasing at $1 \%$ and $0.1 \%$ sPAR depths.

The dissolved oxygen concentration was generally within the range $200-280 \mu \mathrm{mol} \mathrm{L}^{-1}$, with the exception of the $0.1 \%$ sPAR depth in the NATR/WTRA/northern SATL, where concentrations approaching $100 \mu \mathrm{mol} \mathrm{L}^{-1}$ were measured.

200 Plots of dissolved oxygen concentration against salinity (a), temperature (b) and $\mathrm{NO}_{3}{ }^{-}$(c) are presented in Fig. 4. Low dissolved oxygen concentrations measured at $0.1 \%$ sPAR within NATR/WTRA/SATL provinces were associated with lower salinity, temperature, and relatively high $\mathrm{NO}_{3}$. $\mathrm{R}_{\mathrm{NO} 2}$ measurements associated with low-oxygen sampling depths were not anomalously elevated (Fig. 4d). In contrast, the $\mathrm{R}_{\mathrm{NO} 2}$ rate and physio-chemical characteristics of the eddy station identified as $39^{\circ} \mathrm{S}$ distinguished it from the conditions associated with the majority of sampling stations 205 within the transect.

\subsection{Microbial cell distribution and abundance.}

Profiles of chlorophyll-a concentration (Fig. 5a) indicated that within provinces of the North Atlantic, the subsurface maximum generally deepened progressively south. The highest chlorophyll-a concentration was measured within the WTRA, although there was considerable variability in the depth of the chlorophyll-a maximum within this province. Within the South Atlantic, although sampling stations were classified as SATL province, chlorophyll-a profiles could be grouped into four illustrative sub-divisions, characterised by a general shallowing of the chlorophyll-a maximum progressively south.

Pico-eukaryotes (Fig. 5b) had a distribution that was similar to that of chlorophyll-a, in contrast to the profiles of the photosynthetic cyanobacteria Synechococcus and Prochlorococus (results not shown). Bacterial cell distribution (Fig.

215 5c) was comparable between gyres, though less defined within the WTRA, and indicated that the highest bacterial abundance was measured within the relatively well-lit surface ocean.

\subsection{Rates of $\mathrm{R}_{\mathrm{NO} 2}$}

Within the physical, chemical and biological context described above, rates of ammonium oxidation were measured (Fig. 6). For all $\mathrm{R}_{\mathrm{NO} 2}$ data (Fig. 7a-c), the range of volumetric rate measurements was $0.02-13.27 \mathrm{nmol}-\mathrm{N} \mathrm{L}^{-1} \mathrm{~d}^{-1}, \mathrm{n}=88$ triplicated measurements. When integrated from the surface to the $0.1 \% \mathrm{sPAR}$, the range of $\mathrm{R}_{\mathrm{NO} 2}$ was $0.01-0.91 \mathrm{mmol}$ $\mathrm{N} \mathrm{m}^{-2} \mathrm{~d}^{-1}$. By extrapolating the vertically integrated results of each station (excluding $28^{\circ} \mathrm{S}$ and $39^{\circ} \mathrm{S}$ ) from the equator into each hemisphere across a comparable distance (Fig. 8), the concentration of ammonium-N oxidised was calculated to be $0.36 \mathrm{~mol} \mathrm{~N} \mathrm{~d}^{-1}(1 \times 4457 \mathrm{~km}$ transect $)$ and $0.72 \mathrm{~mol} \mathrm{~N} \mathrm{~d}^{-1}(1 \times 4637 \mathrm{~km}$ transect) for the NAG and SAG respectively. The box plot presented in Fig. 7(d) highlights variability within discrete sPAR bands of each hemisphere with mean $\mathrm{R}_{\mathrm{NO} 2}$ values generally skewed towards the lower region of the data range. The distribution of rate measurements is presented in Fig. 7(e) while provincial variability, which averaged 25-fold, is presented in Fig. 7(f). Using a 2 sample t-test assuming unequal variance, $\mathrm{R}_{\mathrm{NO} 2}$ at $1 \% \mathrm{sPAR}$ in the North Atlantic $\left(\mathrm{M}=0.76 \mathrm{nmol} \mathrm{L}^{-1} \mathrm{~d}^{-1}\right.$, $\left.\mathrm{SD}=0.67 \mathrm{nmol} \mathrm{L}^{-1} \mathrm{~d}^{-1}\right)$ was significantly lower than $\mathrm{R}_{\mathrm{NO} 2}$ at $1 \% \mathrm{sPAR}$ in the South Atlantic $\left(\mathrm{M}=1.77 \mathrm{nmol} \mathrm{L}^{-1} \mathrm{~d}^{-1}\right.$, $\left.\mathrm{SD}=1.52 \mathrm{nmol} \mathrm{L}^{-1} \mathrm{~d}^{-1}\right) ; \mathrm{t}(15)=-2.40, \mathrm{p}=0.03$ (no significant difference between hemispheres was found for $14 \%$ and $1 \%$ $50 \mathrm{~m}$ sPAR depths). Volumetric rates of $\mathrm{R}_{\mathrm{NO} 2}$ equated to a $\mathrm{NO}_{2}$ turnover of 0.4-335 days (average 33 days). 
Principle Component Analysis (PCA) of the full set of 24 environmental variables considered (Table 1; Fig. 9) clearly demonstrated that differences between SPAR bands were of the same magnitude or greater than differences along the transect length. PC1, separating the sPAR bands, explained $42.7 \%$ of the total variation while PC2, representing latitudinal variation, explained 23.4\%. This was supported by 2-way ANOSIM with ordered factors, latitude and SPAR band, where the test for differences among latitudes removing differences over sPAR bands $\left(\mathrm{R}^{\mathrm{O}}=0.465, \mathrm{p}<0.001\right)$ gave a lower value for the statistic than the corresponding test for differences among sPAR bands removing latitudinal trends $\left(\mathrm{R}^{\mathrm{O}}=1\right.$, the maximum possible, $\left.\mathrm{p}<0.001\right)$. It was thus decided to analyse relationships among $\mathrm{R}_{\mathrm{NO} 2}$ rates and environmental variables within each sPAR band separately.

Type 2 similarity profiles (SIMPROF) showed evidence for significant correlation structure among variables in all 3 sPAR bands (14\% sPAR band, $\pi=0.296, \mathrm{p}<0.001 ; 1 \%$ sPAR band, $\pi=0.205, \mathrm{p}<0.001 ; 0.1 \%$ sPAR band, $\pi=0.157$, $\mathrm{p}<0.001)$. In the $14 \%$ sPAR band there was a significant relationship $(\rho=0.313, \mathrm{p}=0.025)$ between patterns in $\mathrm{R}_{\mathrm{NO} 2}$ rates and a subset of 3 explanatory variables consisting of light hours, chlorophyll-a and silicate. In the $1 \%$ sPAR band the best subset, also of 3 variables, contained light hours and chlorophyll-a, but with $\mathrm{NO}_{2}$ instead of silicate. The overall relationship was not significant $(\rho=0.170, \mathrm{p}=0.474)$. In the $0.1 \%$ sPAR band the best subset $(\rho=0.415, \mathrm{p}<0.001)$ contained 6 variables, light hours and chlorophyll-a, temperature, $\mathrm{NO}_{2}{ }^{-}, \mathrm{PO}_{4}{ }^{3-}$ and $\mathrm{P}^{*}$. A 2-way search for the best overall match within SPAR bands removing any latitudinal effect selected light hours, chlorophyll-a and silicate, $\rho_{\text {ave }}=0.267, \mathrm{p}<0.001$.

\subsection{Eddy features $28^{\circ} \mathrm{S}$ and $39^{\circ} \mathrm{S}$.}

The majority of the AMT transect ran through quiescent waters free from rapidly varying mesoscale features. The equatorial belt is a region of counter-flowing currents, but these did not lead to any unusual features during this particular AMT campaign. However, anomalous profiles were observed at $28^{\circ} \mathrm{S}$ and $39^{\circ} \mathrm{S}$ (Fig.1), in the form of conspicuously prominent $\mathrm{R}_{\mathrm{NO} 2}$ rates (Fig. 7a-c). The spatial separation of CTD stations ( $\left.300 \mathrm{~km}\right)$ was too great to resolve these physical features. Thus, altimeter and Argo data were obtained subsequent to the cruise in order to provide context to these observations.

Mapped fields of Sea Surface Height (SSH) from CMEMS were used to calculate the mean sea surface topography and the variations about that. A map of the root mean square variability (Fig. 10c) demonstrated that the typical changes north of $35^{\circ} \mathrm{S}$ to be only $\sim 0.1 \mathrm{~m}$; however, even in this region there were a number of highs in the SSH anomaly (deviation from the mean) at the time of sampling the $28^{\circ} \mathrm{S}$ station (Fig. 10a). The anticyclonic feature centred on station $28{ }^{\circ} \mathrm{S}$ had anticlockwise geostrophic flow along the contours in SSHA, whilst the total near-surface velocity recorded by the ADCP was mainly to the southwest. A series of SSHA composites a week apart showed a central anticyclonic feature to be moving westwards, whilst the contemporaneous Argo profiles showed that the thickest mixed layer was located close to the centre of this feature (Fig. 10b). A larger anticyclonic feature was seen $400 \mathrm{~km}$ further to the east. Examination of a time series of SSHA maps and Hovmöller diagrams (not shown) confirmed that these features had travelled from the Agulhas Retroflection, taking 2.5 years to get to this location.

The feature around CTD station $39^{\circ} \mathrm{S}$ was very different. This is the region of the Brazil-Falklands Confluence, where two strong currents collide generating significant mesoscale activity and locally generated eddies. These features also move westwards, but their associated water masses were not from the Agulhas region. In this region the total velocities from the ADCP agreed with the contour directions governing the geostrophic flow. As it is a much more active region, Argo floats do not remain in the region for long, so the examples found (Fig. 10d) were more dispersed than in the previous case. Using the previously stated definition of MLD produced much larger values than at $28{ }^{\circ} \mathrm{S}$, but again supported the concept that the surface layer was much deeper over the highs in SSH than over the lows.

\section{Discussion}

\subsection{Overview and objectives.}

275 This study measured rates of ammonium oxidation within the photic zone across an extended spatial scale $(13,000 \mathrm{~km})$, reporting significant variability between and within provinces of the oligotrophic Atlantic Ocean between $\sim 49^{\circ} \mathrm{N}$ and $\sim 39^{\circ} \mathrm{S}$. Insights add to evidence that surface ocean nitrification is an important component of pelagic nitrogen cycling that modifies the inorganic nitrogen inventory. Particular features of interest included a significant 
hemispheric difference in ammonium oxidation and elevated rates associated with mesoscale eddy features. Analysis of potential links between ammonium oxidation and routinely measured ecosystem variables indicated significant covariability between ammonium oxidation, chlorophyll-a concentration, the duration of the light phase and silicate concentration, alluding to an association between ammonium oxidation and product(s) of photosynthetic activity. However, a significant fraction $(\sim 35 \%)$ of variability in ammonium oxidation remained unexplained, indicating that additional factors were excluded from this analysis. We first consider the biogeochemical context to the study before presenting rate observations and insights from statistical analysis.

\subsection{Physical context}

A thermal range of $\sim 17{ }^{\circ} \mathrm{C}$ typically existed in vertical $250 \mathrm{~m}$ water column profiles. While temperature has a direct impact on rates of biological activity, the physical stability of the water column caused by thermal stratification establishes spatially distinct biogeochemical niches (Giovanoni and Vergin, 2012). Within the well-lit surface ocean that includes the $14 \%$ sPAR, defined as the region between the sea-surface and the deep chlorophyll-a maximum (DCM), turbulent mixing with nutrient rich deep water is supressed and biological activity maintains extremely low inorganic nutrient concentrations. Relatively sharp physio-chemical gradients at depths similar to the $1 \%$ sPAR create a niche where low light-adapted phototrophs access relatively high inorganic nutrient concentrations, forming the DCM. At greater depths, incorporating the $0.1 \%$ sPAR and typically referred to as the twilight zone (approximately 100$1000 \mathrm{~m}$ ), water continues to cool. While there is relatively little information for the temperature sensitivity of nitrification in the open ocean, Horak et al., (2013) demonstrated a relative insensitivity to a temperature range of 8$20{ }^{\circ} \mathrm{C}$ in their study of a fjord-like basin, although low $\mathrm{pH}$ at the study site may have constrained any temperature response (Beman et al., 2011).

The range in salinity was $\sim 3.2$, with limits defined by notably fresher water in the sub-tropical region (WTRA), a feature potentially related to intense rainfall within the inter-tropical convergence zone, and relatively high salinity in the central Atlantic gyres. While a contributory role for salinity in shaping nitrifying community structure has been identified in studies of estuarine sediments (Francis et al., 2003; Bernhard et al., 2010), such gradients are considerably more extreme than those of the open oceans, where little, if any information is available to describe its influence upon variability in nitrification rate.

305 The attenuation of light with depth leads to progressively decreasing daily light dose, ranging 2 orders of magnitude across the three $\mathrm{R}_{\mathrm{NO} 2}$ sampling depths (Fig. 2c). Superimposed upon diel and depth-related light variability was a seasonal increase in day-light duration progressively south, associated with the transition from boreal autumn to austral spring. Seasonally variable characteristics are evident in the photic zone of sub-tropical Atlantic gyres driven by changes in solar insolation (McClain et al., 2004). Weaker solar insolation during winter supresses DCM productivity, allowing higher nutrient concentrations to pass this 'biological filter' into the well-lit surface ocean. This mechanism supports higher chlorophyll-a concentrations in the surface ocean (Taylor et al., 1986) and would presumably stimulate broader biological activity, including the decomposition of recently produced organic matter and the regeneration of nutrients. Seasonality in the rate of nitrification was not evident in the study of Yool et al. (2007), although such a signal may exist (Newell et al., 2013).

Evidence demonstrates that light structures the distribution of nitrifying organisms, whose activity may be supressed within the photic zone (Shiozaki et al., 2016; Olson et al., 1981). Further, by poorly competing with photosynthetic plankton for $\mathrm{NH}_{4}{ }^{+}$resource, nitrifier distribution and activity is indirectly constrained by the light regime (Ward, 1985; Smith et al., 2014). While the light/dark cycle may lead to a diel variability in nitrifying activity (increasing at night with the recovery from light inhibition; Smith et al., 2014), resource competition with phytoplankton may persist due to their capacity for dark $\mathrm{N}$-assimilation, especially of $\mathrm{NH}_{4}{ }^{+}$(Clark et al., 2002).

\subsection{Chemical context}

In terms of the chemical context to the study, characteristically low concentrations of $\mathrm{NO}_{3}{ }^{-}, \mathrm{PO}_{4}{ }^{3-}$ and $\mathrm{Si}(\mathrm{OH})_{4}$ were evident within the well-lit surface ocean (14\% sPAR), progressively increasing at $1 \%$ and $0.1 \%$ sPAR (Fig. 3.a, b, f). This distribution is consistent with biological draw-down, likely dominated by nutrient acquisition by phototrophs (Poulton et al., 2006; Marañon et al., 2000). Extremely high concentrations were a prominent feature of nutrient profiles within the deep equatorial region. 
In the mesopelagic ocean, nitrification maintains the accumulation of $\mathrm{NO}_{3}{ }^{-}$, while the diapycnal nutrient flux to the surface open ocean is relatively weak, especially during periods of low wind energy input. $\mathrm{NO}_{3}{ }^{-}$supplied via nitrification in the photic zone is either extremely low (Clark et al., 2008; Newell et al., 2013) or below detection (Lomas et al., 2009). Alternative $\mathrm{NO}_{3}{ }^{-}$and $\mathrm{PO}_{4}{ }^{3-}$ sources to the surface ocean includes introduction as a component of atmospheric dust (Gruber and Sarmiento, 1997; Baker and Jickells, 2017), subsurface injections via the action of internal tides over mid-ocean ridges (Tuerena et al., 2019) or the passage of mesoscale eddies (McGillicudy et al., 1998; Oschilies and Garcon, 1998). No direct correlation between nitrification and $\mathrm{NO}_{3}{ }^{-}$concentration has been reported. A relationship with $\mathrm{PO}_{4}{ }^{3-}$ availability has been demonstrated in water treatment systems (de Vet et al., 2012), although there is no evidence to support this correlation in low nutrient environments.

Analytical capacity for nano-molar $\mathrm{NH}_{4}{ }^{+}$measurements was unavailable for this study, creating a potentially significant shortfall in the data set, since $\mathrm{NH}_{4}{ }^{+}$concentration has been demonstrated to influence the activity, distribution and composition of nitrifying communities (Bouskill et al., 2012; Smith, 2016). As the primary resource for nitrification, it is intuitive to expect a direct relationship between ammonium oxidation rate and $\mathrm{NH}_{4}{ }^{+}$concentration

340 (Smith et al., 2016), evidence for which supports the representation of this process as the specific rate $\left(\mathrm{d}^{-1}\right.$; Yool et al., 2007). However, this correlation is not consistently demonstrated (Bouskill et al., 2012) and the process of $\mathrm{NH}_{4}{ }^{+}$ oxidation may exhibit saturation kinetics (Shiozaki et al., 2016; Martens-Habbena et al., 2009).

A phosphate excess similar to $0.2 \mu \mathrm{mol} \mathrm{L} \mathrm{L}^{-1}$ was evident at all depths in the WTRA and SATL (Fig. 3c). This feature is related to both source waters (Sarmiento et al., 2004) and the interhemispheric difference in N-fixation, supported by micro-nutrient inputs via atmospheric dust deposition (Baker and Jickells, 2017), leading to $\mathrm{P}^{*}$ drawdown in the North Atlantic (Moore et al., 2009). There is no evidence of a direct relationship between $\mathrm{P}^{*}$ and nitrification rate. However, in Atlantic regions of enhanced $\mathrm{N}$-fixing activity, evidence suggests that organic material produced by diazotrophs is recycled within the surface ocean (Mulholland, 2007). While nitrification has rarely been measured simultaneously with $\mathrm{N}$-fixation (both were measured by Raes et al 2020 although no relationship was reported; it has been implied that N-

350 fixation leads to an increase in the nitrate inventory; Mills et al., 2004), it likely has a role in redistributing newly fixed nitrogen, which is directly released as $\mathrm{NH}_{4}{ }^{+}$or regenerated as $\mathrm{NH}_{4}{ }^{+}$from the decomposition of released dissolved organic nitrogen (Glibert and Bronk, 1994; Mulholland et al., 2004; Newell et al., 2011). During this study, the seasonal low in dust deposition to the North Atlantic may have shifted resource constraints towards phosphate-Fe co-limitation, with implications for the extent and rate of $\mathrm{N}$-fixation, and speculatively extending to the subsequent processes of $\mathrm{N}$ remineralisation.

A Primary Nitrite Maximum (PNM) was evident over the entire transect (Fig. 3e). A range of $0.05-0.50 \mu \mathrm{mol} \mathrm{L}^{-1}$ was measured, although sampling resolution may have limited the extent to which this feature was resolved (Beman, 2012; Meeder et al., 2012). Evidence suggests that nitrification has an important role in the formation and maintenance of the PNM against diffusive forces (Peng et al., 2018; Beman et al., 2012; Newell et al., 2013; Buchwald and Casciotti, 2013; Santoro et al., 2013; Meeder et al., 2012), with potential contributions from $\mathrm{NO}_{2}{ }^{-}$release by phytoplankton (Beman et al., 2012; Santoro et al 2013). This study is unable to inform the debate surrounding PNM formation as the isotope dilution approach adopted here does not discriminate between the processes contributing to $\mathrm{NO}_{2}{ }^{-}$regeneration (ammonium oxidation, algal $\mathrm{NO}_{2}^{-}$release and potentially a photolytic route which produces $\mathrm{NO}_{2}^{-}$from $\mathrm{NO}_{3}^{-}$(Zafiriou and True, 1979) and humic substances (Kieber and Seaton, 1999)). The release of $\mathrm{NO}_{2}{ }^{-}$by phytoplankton is most frequently associated with an intracellular resource imbalance linked to dynamic transitions (e.g. vertical mixing across a light gradient; Santoro et al., 2013; Lomas and Lipschultz, 2006; Meeder et al., 2012) which indicates that ammonium oxidation likely dominated the contribution to $\mathrm{R}_{\mathrm{NO} 2}$. Across all depths, the oxidation of $\mathrm{NH}_{4}{ }^{+}$lead to an average $\mathrm{NO}_{2}{ }^{-}$ turnover of 38.5 days (range 0.4-335 days) within the North Atlantic Gyre compared to an average of 37 days (range 2.9-160 days) for the South Atlantic Gyre. For the PNM, a range of 3-40 days was reported within the California current system (Santoro et al., 2013) and 33-178 days in the Arabian Sea (Buchwald and Casciotti, 2013).

The dissolved oxygen concentration was generally observed to be $\sim 200-300 \mu \mathrm{mol} \mathrm{L}^{-1}$, with variability linked to seawater temperature (Fig. 4d). Dissolved oxygen concentration has been shown to structure the activity and distribution of nitrifying organisms (Ward, 2002, Beman et al., 2008; 2012), especially within low oxygen environments (Beman et al., 2008; Bouskill et al., 2012). A low oxygen feature of the $0.1 \%$ sPAR equatorial upwelling water was distinguished in a series of correlation plots (Fig. 4 a-c), linked to relatively low temperature and salinity in combination with a very high $\mathrm{NO}_{3}{ }^{-}$concentration. This well documented oxygen minimum region is related to large scale circulation causing weak ventilation (Kartensen et al., 2008). This relative extreme in a combination of physico- 
chemical conditions did not result in distinct elevations of $\mathrm{R}_{\mathrm{NO} 2}$ (Fig. 4d). Similar results were noted by Shoizaki et al., (2016) in the North Pacific Ocean, where dissolved oxygen concentrations approaching $50 \mu \mathrm{mol} \mathrm{L} \mathrm{L}^{-1}$ were not associated with an enhanced rate of nitrification. Nitrification within low-oxygen environments is of interest as it links $\mathrm{N}$-inputs to marine environments via $\mathrm{N}$-fixation to $\mathrm{N}$-losses via denitrification and anaerobic ammonium oxidation (annamox), processes which are characteristically associated with marine regions of extremely low oxygen concentration (Francis et al., 2007; Ward et al., 1989).

\subsection{Biological context}

Profiles of biological parameters (chlorophyll-a, pico-eukaryote and bacterial abundance) demonstrated apparent vertical structure. The chlorophyll-a distribution indicated that photosynthetic cells were present throughout the depth range used for $\mathrm{R}_{\mathrm{NO} 2}$ measurements. The presence of measurable chlorophyll-a implied the potential production and release of dissolved organic matter, in addition to organic matter released upon cell rupture (via grazing or viral attack). In contrast to the deep chlorophyll-a and picoplankton abundance maxima, bacterial cell profiles tended to describe higher abundance towards the well-lit region of the water column. Assuming that bacterial cell abundance reflected resource availability, the observed distribution implied the availability of photosynthetically derived labile DOM throughout the photic zone (noting that the DCM represents only a small fraction of water column productivity and biomass; Marañon et al., 2000), and consequently the regeneration of $\mathrm{NH}_{4}{ }^{+}$. While the subsequent fate of regenerated $\mathrm{NH}_{4}{ }^{+}$would relate to environmental factors that shape the open ocean ecosystem, molecular evidence supports the potential for nitrifying activity throughout the surface ocean (Church et al., 2010; Santoro et al., 2010).

\section{5 $\mathrm{R}_{\mathrm{NO} 2}$, measurements within the study.}

Ammonium oxidation was consistently measured at three sPAR depths within the physical, chemical and biological context described above (Fig. 6; Fig. 7a-c), indicating that $\mathrm{NH}_{4}{ }^{+}$was available to support an oxidation rate of 0.02$13.27 \mathrm{nmol} \mathrm{L}^{-1} \mathrm{~d}^{-1}$. When integrated between the surface and $0.1 \% \mathrm{sPAR}$, the range was $0.01-0.91 \mathrm{mmol} \mathrm{m}^{-2} \mathrm{~d}^{-1}$. In their study of the tropical eastern Pacific and Gulf of California, Beman et al., (2012) report a range of 1.38-7.72 $\mathrm{mmol} \mathrm{m}^{-2}$ $\mathrm{d}^{-1}$ in the upper $300 \mathrm{~m}$ although only $1.5-42 \%$ of integrated ammonium oxidation was associated with depths shallower than $1 \%$ sPAR. Assuming a range of $10-100 \mathrm{nmol} \mathrm{L}^{-1} \mathrm{NH}_{4}{ }^{+}$at sampling depths throughout the transect, a range consistent with historical measurements (Clark et al., 2008; British Oceanographic Data Centre data archives; www. BODC.ac.uk), a specific rate of $0.011-0.113 \mathrm{~d}^{-1}$ was derived. This basin-scale range is comparable to that typically applied in biogeochemical models, reported to be 0.02 to $0.1 \mathrm{~d}^{-1}$ (Moore et al., 2002; Wang et al., 2006; Christian et al., 2002; Jiang et al., 2003), although in their global model Yool et al. apply a value of $0.2 \mathrm{~d}^{-1}$ (Yool et al., 2007).

The vertical distribution and magnitude of $\mathrm{R}_{\mathrm{NO} 2}$ rates were consistent with previous observations, whereby low but detectable rates were measured within the well-lit ocean, a peak in ammonium oxidation rates was measured at $1 \%$ sPAR, and a decline in rates was measured as depth increased below $1 \%$ sPAR (Fig. 6; 7d, e; Al-Qutob et al., 2002;

410 Santoro et al., 2013; Shiozaki et al., 2016; Newell et al., 2013; Peng et al., 2018; Beman et al., 2012). The causes for this distribution are a continuing subject of debate, but ultimately reflect a balance between multiple factors including the provision of labile organic matter supporting the regeneration of $\mathrm{NH}_{4}{ }^{+}$, competition for this resource from other microbes including photosynthetic cells, and grazing pressure by mixotrophs and heterotrophic protists upon the nitrifying community.

A striking feature of the $\mathrm{R}_{\mathrm{NO} 2}$ data set was the $1 \%$ sPAR rate range associated with south Atlantic stations (Fig. 7d), the mean of which was significantly greater than that measured in the North Atlantic Gyre. Indeed, by extrapolating vertically integrated values across a comparable distance into each hemisphere from the equator, we derive that the amount of $\mathrm{NH}_{4}{ }^{+}-\mathrm{N}$ oxidised to $\mathrm{NO}_{2}^{-}$was $0.36 \mathrm{~mol} \mathrm{~N} \mathrm{~d}^{-1}$ over a $1 \mathrm{~m} \mathrm{x} 4457 \mathrm{~km}$ distance north of the equator and 0.72 mol N d${ }^{-1}$ over a $1 \mathrm{~m} \mathrm{x} 4637 \mathrm{~km}$ distance south of the equator. We are unable to conclusively explain this novel

420 distinction between hemispheres. However, it is recognised that the Atlantic gyres have persistent biogeochemical differences in dust deposition, the inorganic nutrient regime and biological features such as $\mathrm{N}$-fixation (Baker and Jickells, 2017; Moore et al., 2009; Ussher et al., 2013) that likely shape and influence broader biological activity within the surface ocean of each Atlantic gyre. Seasonality may be an additional component that contributes towards this hemispheric distinction. In their analysis of multiple AMT transects, Poulton et al. (2006) noted that high rates of carbon fixation at the sub-surface chlorophyll-a maximum characterizing SATL stations during October were potentially linked to the onset of spring conditions. At this time, nutrients supplied by winter mixing to the sub-surface 
chlorophyll-a maximum in combination with basin scale changes in irradiance, support the growth of larger eukaryotic phytoplankton (Letelier, 2004). The associated seasonal production of organic material would inevitably lead to an increase in decomposition and inorganic nutrient regeneration (including nitrification). Multivariate analysis, which identified an association between ammonium oxidation and chlorophyll-a, light duration and nutrients, provided support for this association, as discussed below.

Multivariate approaches were used to investigate potential structure within the data and to examine relationships between ammonium oxidation and environmental variables. However, it is first worth considering limitations of the data set used for this analysis. While there is strong evidence to suggest that ammonium oxidation reflected ammonium oxidation activity rather than alternative sources of $\mathrm{NO}_{2}{ }^{-}$, the measurement does not distinguish between archaeal or bacterial nitrifiers, which likely dominate separate niches within depth profiles (Benman et al., 2012). Nor does it consider the influence of changes in nitrifier community composition along the extended transect. Microbial cell abundance is no indication of the activity of specific microbial groups, or their importance to biological processes. Chlorophyll-a concentration does not reflect changes in species composition, or necessarily biomass, which are known to change in response to environmental forcing within the Atlantic Ocean (Poulton et al 2006). Within these limitations, the PCA ordination of the entire data set (Fig. 9) demonstrated greater similarity within a sampling depth, equating to horizontal scales of hundreds of kilometres, than between sampling depths equating to vertical scales of tens of meters. A similar result was previously observed (Poulton et al., 2017), implying that distinct niches exist between depth horizons.

Statistical analysis aimed to identify the subset of explanatory variables that, in combination, best matched the observed pattern of ammonium oxidation rates. This match was provided by a combination of chlorophyll-a concentration, light duration and silicate concentration. A similar outcome was reported by Shiozaki et al., (2016) in their study of the oligotrophic North Pacific, in which a correlation between the activity of photosynthetic cells and ammonium oxidation was reported, although this relationship was not consistently observed at all sampling stations. Chlorophyll-a and light duration as explanatory variables were common to all three sampling depths while depthspecific relationships incorporated additional variables. These results implied that, either directly or indirectly, ammonium oxidation responded to a product of actively photosynthesising cells (as opposed to other microbes identified by AFC). The production and release of labile dissolved organic matter during photosynthetic activity and its subsequent decomposition to regenerate $\mathrm{NH}_{4}{ }^{+}$is an intuitive (and potentially spatially/temporally close) link between photosynthetic cells and nitrifying organisms that could be supported by this insight. However, a role for silicate has not previously been reported, potentially highlighting a link to diatoms. Diatoms are relatively large, mineralising phytoplankton capable of rapid growth that contribute significantly to organic matter production and export in oligotrophic environments (Klass and Archer, 2006; Scharek et al., 1999). Alternatively, and perhaps more likely, silicate may be viewed as a tracer for sporadic nutrient inputs from below the nutricline (to include $\mathrm{NO}_{3}{ }^{-}, \mathrm{PO}_{4}{ }^{3-}$ ) that stimulate short-term growth of photosynthetic cells in oligotrophic environments (Poulton et al., 2006). In contrast to other resources supplied by vertical mixing (e.g. $\mathrm{NO}_{3}{ }^{-}, \mathrm{PO}_{4}{ }^{3-}$ ), silicate is only utilised by diatoms which represent a fraction of the microbial community. It is reasonable to expect that following a localised mixing event, elevated silicate concentrations persist for longer than the simultaneously introduced $\mathrm{NO}_{3}{ }^{-}$and $\mathrm{PO}_{4}{ }^{3-}$, which are drawn down due to localised increases in primary productivity. Silicate effectively becomes a tracer for water that hosts the products of active or recently enhanced productivity, with subsequent decomposition and nutrient regeneration.

The current view of low nutrient environments sees a dominant role for the picoplankton community which supports the microbial food web, with the sporadic growth of large phytoplankton following episodic nutrient inputs due to localised short-term physical instability (Carpenter et al., 1999; Scharek et al., 1999; Dandonneau et al., 2003; Poulton et al., 2006). Increased nutrient availability favours larger and faster growing cells that outcompete the picoplankton to transiently dominate the microbial community in open ocean environments (Kiørbe, 1993). Organic matter released during such transient events (directly from living cells or following cell lysis) would support a short-term localised increase in N-regenerating activity, including ammonium oxidation. Evidence indicates that archaea, which frequently dominate the euphotic zone nitrifying community, possess a high resource affinity and respond rapidly to $\mathrm{NH}_{4}{ }^{+}$pulses in culture (Martens-Habbena et al., 2009; Beman et al., 2012). Whether the statistically significant link between rates of ammonium oxidation and a combination of chlorophyll-a, light duration and silicate relates to diatoms specifically (which have an absolute requirement for silicate and are obligate phototrophs i.e. they do not express mixotrophy unlike most other photosynthetic plankton, a nutritional mode that affords flexibility in resource limited environments and decreases dependence upon photosynthetic $\mathrm{CO}_{2}$ fixation; Mitra et al., 2014) or more likely relates to a broader 
stimulation of transient micro-plankton growth remains to be tested. Should nitrifying activity be responding to a chain of events in the very recent past, instantaneous rates of nitrification may not be fully explained by routine measurements of extant environmental conditions, such as those used in the present study. A detailed examination of labile DON production and decomposition may be required in combination with studies of nitrification.

Conspicuously prominent ammonium oxidation rates were associated with stations $28^{\circ} \mathrm{S}$ and $39^{\circ} \mathrm{S}$, with measured ranges of 1.5-8.6 $\mathrm{nmol} \mathrm{L}^{-1} \mathrm{~d}^{-1}$ and 1.3-13.3 $\mathrm{nmol} \mathrm{L}^{-1} \mathrm{~d}^{-1}$ respectively (Fig. 4d; 7a-c). Selected biogeochemical characteristics further distinguished station $39^{\circ} \mathrm{S}$ (high $\mathrm{P}^{*}, \mathrm{O}_{2}$ concentration, lower salinity and temperature; Fig. $3 ; 4$ ) although those of station $28{ }^{\circ} \mathrm{S}$ were typical of the province. The use of Earth Observation data (sea surface temperature, ocean colour) revealed no anomalous features co-incident with these stations. However, Sea Surface Height Anomaly (SSHA) data evidenced that $28^{\circ} \mathrm{S}$ and $39^{\circ} \mathrm{S}$ were associated with mesoscale eddy features at the point of sampling (Fig. 9). Analysis revealed that no other stations of this study coincided with discernible mesoscale eddy features at the point of sampling.

Eddy $39^{\circ} \mathrm{S}$ was locally generated. In contrast, eddy $28^{\circ} \mathrm{S}$ likely originated within the Agulhas Retroflection, traversing and potentially influencing SAG biogeochemistry before dissipating on the Brazilian shelf some 3.5 years later. Nencioli et al., (2018) tracked similar features, showing that they provided a coherent transport of water masses, preserving some of the physical and biological signals over more than two years. The vertical flux of inorganic nutrients induced by the dynamics of traversing eddies has been argued to balance the Sargasso Sea nutrient budget (McGillicuddy et al., 1998). Similarly, the $\mathrm{NO}_{3}{ }^{-}$deficit observed between new production requirements and diffusive $\mathrm{NO}_{3}{ }^{-}$supplies in the Atlantic Gyres may be reconciled to some extent by eddy dynamics (Planas et al., 1999). While the nutrient regime of $28{ }^{\circ} \mathrm{S}$ was comparable to the provincial average, elevated ammonium oxidation (some 2-6 times higher than the provincial average) implied unusual biological activity; such activity is not sustained in isolation, but

500 must couple (over appropriate scales of space/time) to the activity of other biological processes (e.g. nutrient acquisition, photosynthetic growth, DON production and decomposition, $\mathrm{NO}_{2}{ }^{-}$oxidation), presumably supported by new nutrients physically introduced into the photic zone by eddy dynamics. Unfortunately, given that only 3 ammonium oxidation rate observations were made at station $28^{\circ} \mathrm{S}$, located at the edge of a feature which measured approximately $300 \mathrm{~km}$ in diameter, little can be said about how representative of the feature this activity is, the relevance to broader nitrogen cycling activity or its significance as a source of atmospheric $\mathrm{N}_{2} \mathrm{O}$ (Dore and Karl, 1996).

\subsection{Conclusions}

This study reported relatively high-resolution measurements of ammonium oxidation rate at the oceanic basin scale. Ammonium oxidation took place at all locations investigated, adding to evidence that this process is widely distributed and active within the sunlit ocean. Considering all rate data, results implied that more active nitrogen cycling took place

510 in the South compared to the North Atlantic Gyre. While seasonality may contribute towards this hemispheric distinction, we speculate that this is a persistent feature. Historical AMT data sets demonstrate the broad inter-annual consistency of biogeochemical distributions and features to which ammonium oxidation rate significantly related. Should this testable hypothesis be substantiated, it would allude to a broader biogeochemical distinction between Atlantic gyres as the process of ammonium oxidation is intrinsically linked to other microbial processes that cycle 515 resources. By extension, as chemolithoautotrophs, nitrifiers fix $\mathrm{CO}_{2}$ concurrently with nitrifying activity. Nitrifier mediated C-fixation in the South Atlantic Gyre would also exceed that of the North. A statistical analysis of observational data indicated that $\sim 65 \%$ of variability in ammonium oxidation rate was explained through co-variability with environmental variables. A previously observed link to photosynthetic cells (Shiozaki et al., 2016) was supported here, and summarised as a significant relationship between ammonium oxidation rate and a combination of

520 chlorophyll-a concentration, light duration and silicate. We speculate that as an indication of recent physical instability, silicate transiently marks seawater that hosts the products of active or recently enhanced photosynthetic productivity, with subsequent organic matter decomposition and nutrient regeneration. This leads us to conclude that a role for DOM, and specifically the short-term production, release and decomposition of labile material is amongst the factors contributing to the unexplained variability in ammonium oxidation.

Two mesoscale eddies supported very high rates of ammonium oxidation, an observation previously unreported. Although the limited number of observations do not permit a meaningful analysis, results highlight the possibility that eddies which traverse the South Atlantic Gyre may disproportionately influence mixed layer biogeochemistry and ocean-atmosphere gas exchange. 


\section{Data availability}

530 All AMT 19 metadata can be downloaded from the British Oceanographic Data Centre website: https://www.bodc.ac.uk/data/hosted data systems/amt/, in addition to ammonium oxidation rate data (doi:10.5285/56df6379-5b2b-160b-e053-6c86abc01f07) and flow cytometry data (10.5285/a2104adc-e994-6789-e0536c86abc0d557).

\section{Author contribution}

535 DRC - designed experiments, undertook sample and data analysis, written manuscript; APR - conducted N-cycle fieldwork investigations, contributed to manuscript preparation; $\mathrm{CF}$ - conducted $\mathrm{N}$-cycle fieldwork investigations; $\mathrm{CH}$ conducted inorganic nutrient analysis of fieldwork samples; LA - mass spectrometry sample analysis; PJS - statistical analysis, contributed to manuscript preparation; GDQ - satellite data analysis, contributed to manuscript preparation; SG - satellite data analysis; GL - data analysis, contributed to manuscript preparation; GT- conducted flow cytometry analysis of fieldwork samples, contributed to manuscript preparation.

\section{Competing interests}

The authors declare that they have no conflict of interest.

\section{Acknowledgments}

We thank the crew of the AMT19 cruise. MSLA data were obtained and analysed through the NERC Earth Observation Data Acquisition and Analysis Service (NEODAAS). This is contribution number 320 of the AMT program, which was also supported by the Natural Environment Research Council funded Microbial Carbon Pump project (Clark Co-I; NE/R011087/1). We acknowledge funding from the UKRI through the National Capability Long-term Single Centre Science Programme, Climate Linked Atlantic Sector Science (Grant no. NE/R015953/1).

\section{References}

Al-Qutob, M., Hase, C., Tilzer, M. M., and Lazar, B.: Phytoplankton drives nitrite dynamics in the Gulf of Aqaba, Red Sea. Marine Ecology Progress Series. 239, 233-239, doi:10.3354/meps239233, 2002.

Azam, F., Fenchel, T., Field, G., Graf, J. S., Meyer-Reil, L. A., and Thingstad, F.: The ecological role of water-column microbes in the sea. Mar. Ecol. Prog. Ser. 10, 257-263. doi:10.3354/meps010257, 1983.

Baker, A. R., and Jickells, T. D.: Atmospheric deposition of soluble trace elements along the Atlantic Meridional Transect (AMT). Prog. Oceanogr. 158, 41-51, doi:10.1016/j.pocean.2016.10.002, 2017.

Beman, J. M., Popp, B. N., and Francis, C. A.: Molecular and biogeochemical evidence for ammonia oxidation by marine Crenarchaeota in the Gulf of California. ISME J 2: 429-441, doi:10.1038/ismej.2007.118, 2008.

Beman, J., Chow, C-E., King, A., Feng, Y., Fuhrman, J. A., Andersson, A., Bates, N.R., Popp, B. N. and Hutchins, D.A.: Global declines in oceanic nitrification rates as a consequence of ocean acidification. Proc. Natl. Acad. Sci. USA 108, 208-213, doi:10.1073/pnas.1011053108 2011, 2011.

Beman, J. M., B. N. Popp, S. E. and Alford. S. E.: Quantification of ammonia oxidation rates and ammonia-oxidizing archaea and bacteria at high resolution in the Gulf of California and eastern tropical North Pacific Ocean. Limnol. Oceanogr. 57, 711- 726. doi:10.4319/lo.2012.57.3.0711, 2012.

Bernhard, A. E., Landry, Z. C., Blevins, A., de la Torre, J. R., Giblin, A. E., and Stahl, D. A.: Abundance of ammoniaoxidizing Archaea and Bacteria along an estuarine salinity gradient in relationship to potential nitrification rates, Appl. Environ. Microbiol. 76, 1285-1289, doi:10.1128/AEM.02018-09, 2010.

Blackburn, T. H.: Method for measuring rates of $\mathrm{NH}_{4}{ }^{+}$turnover in anoxic marine sediments, using a ${ }^{15} \mathrm{~N}^{-\mathrm{NH}_{4}}{ }^{+}$dilution technique. Appl. Environ. Microbiol. 37, 760-765, 1979. 
Bouskill, N. J., Eveillard, D., Chien, D., Jayakumar, A., Ward, B. B.: Environmental factors determining ammoniaoxidizing organism distribution and diversity in marine environments. Environ. Microbiol. 14, 714-29, doi: 10.1111/j.1462-2920.2011.02623.x, 2012.

Buesseler, K. O., and Boyd, P. W.: Shedding light on processes that control particle export and flux attenuation in the twilight zone of the open ocean. Limnol. Oceanogr. 54, 1210-1232. doi:10.4319/lo.2009.54.4.12102009, 2009.

Buchwald, C., and Casciotti, K. L.: Isotopic ratios of nitrite as tracers of the sources and age of oceanic nitrite. Nat. Geosci. 6, 308-13, doi:10.1038/ngeo1745, 2013.

Caperon, J., Schell, D., Hirota, J., and Laws, E.: Ammonium excretion rates in Kaneohe Bay, Hawaii, measured by a ${ }^{15} \mathrm{~N}$ isotope dilution technique. Mar. Biol. 54, 33-40, 1979.

Carpenter, E. J., Montoya, J. P., Burns, J., Mulholland, M. R., Subramaniam, A., and Capone, D. G.: Extensive bloom of a $\mathrm{N}_{2}$-fixing diatom/cyanobacterial association in the tropical Atlantic Ocean. Mar. Ecol. Prog. Ser. 185, 273283, doi: 10.3354/meps185273, 1999.

Christian, J. R., Verschell, M. A., Murtugudde, R., Busalacchi, A. J., and McClain, C. R.: Biogeochemical modelling of the tropical Pacific Ocean. I: Seasonal and interannual variability. Deep-Sea Research Part II 49, 509-543, doi:10.1016/S0967-0645(01)00110-2, 2002.

Church, M. J., Karl, D. M., and DeLong, E. F.: Abundances of crenarchaeal amoA genes and transcripts in the Pacific Ocean, Environ. Microbiol., 12, 679-688, 2010. doi:10.1111/j.1462-2920.2009.02108.x, 2010.

Clark, D. R., Flynn, K. J., Owens, N. J. P.: The large capacity for dark nitrate-assimilation in diatoms may overcome nitrate limitation of growth. New Phytol. 155, 101-108, doi:10.1046/j.1469-8137.2002.00435.x, 2002.

Clark, D. R., Fileman, T. W., and Joint, I.: Determination of ammonium regeneration rates in the oligotrophic ocean by gas chromatography/mass spectrometry. Mar. Chem. 98, 21-130, doi:10.1016/j.marchem.2005.08.006, 2006.

Clark, D. R., Rees, A. P., and Joint, I.: A method for the determination of nitrification rates in oligotrophic marine seawater by gas chromatography/mass spectrometry. Mar. Chem. 103, 84-96, doi: 10.1016/j.marchem.2006.06.005, 2007.

Clark, D. R., Rees, A. P., and Joint, I.: Ammonium regeneration and nitrification rates in the oligotrophic Atlantic Ocean: Implications for new production estimates. Limnol. Oceanogr. 53, 52-62, doi:10.2307/40006149, 2008.

Clark, D. R., Brown, I. J., Rees, A. P, Somerfield, P. J., and Miller, P. I.: The influence of ocean acidification on nitrogen regeneration and nitrous oxide production in the northwest European shelf sea. Biogeosciences 11, 4985-5005, doi:10.5194/bgd-11-3113-2014, 2014.

Clarke, K. R., and Warwick, R. M.: Quantifying structural redundancy in ecological communities. Oecologia 113, 278289, doi:10.1007/s004420050379, 1998.

Clarke, K. R., Somerfield, P. J., and Gorley, R. N.: Testing of null hypotheses in exploratory community analyses: similarity profiles and biota-environment linkage. J. Exp. Mar. Biol. Ecol. 366, 56-69, doi: 10.1016/j.jembe.2008.07.009, 2008.

Clarke, K. R., Gorley, R. N., Somerfield, P. J., and Warwick, R. M.: Change in marine communities: an approach to statistical analysis and interpretation, 3rd edn. PRIMER-E, Plymouth. 256 pp, 2014.

Dandonneau, Y., Vega, A., Loisel, H., du Penhoat, Y., and Menkes, C.: Oceanic Rossby waves acting as a hay rake for ecosystem floating by-products. Science 302, 1548-1551, doi:10.1126/science.1090729, 2003.

Dore, J. E., and Karl, D. M.: Nitrification in the euphotic zone as a source for nitrite, nitrate and nitrous oxide at Station ALOHA. Limnol. Oceanogr. 41, 1619-1628, doi:10.4319/lo.1996.41.8.1619, 1996. 
Emerson, S., Mecking, S., and Abell, J.: The biological pump in the subtropical North Pacific Ocean: Nutrient sources, Redfield ratios, and recent changes. Global Biogeochem. Cy. 15, 535-554, doi:10.1029/2000GB001320, 2001.

Eppley, R.W., and Peterson, B. J.: Particulate organic matter flux and planktonic new production in the deep ocean. Nature 282, 677-680, 1979.

Fawcett, S. E., Ward, B. B., Lomas, M. W., and Sigman, D. M.: Vertical decoupling of nitrate assimilation and nitrification in the Sargasso Sea. Deep-Sea Research I 103, 64-72, doi:10.1016/j.dsr.2015.05.004, 2015.

Francis, C. A., O'Mullan, G. D., and Ward, B. B.: Diversity of ammonia monooxygenase (amoA) genes across environmental gradients in Chesapeake Bay sediments. Gobiology 1:129-140, doi:10.1046/j.14724669.2003.00010.x, 2003.

Francis, C., A., Beman, J. M., and Kuypers, M. M. M.: New processes and players in the nitrogen cycle: The microbial ecology of anaerobic and archaeal ammonia oxidation. ISMEJ. 1, 19-27, doi:10.1038/ismej.2007.8, 2007.

Giovanoni, S. J., and Vergin, K. L.: Seasonality in ocean microbial communities. Science, 335, 671-676, doi: 10.1126/science.1198078, 2012.

Glibert, P. M., and Bronk, D. A.: Release of dissolved organic nitrogen by marine diazotrophic cyanobacteria, Trichodesmium spp., Appl. Environm. Microbiol., 60, 3996-4000, doi:10.1128/AEM.60.11.3996-4000.1994, 1994.

Gruber, N., and Sarmiento, J. L.: Global patterns of marine nitrogen fixation and denitrification. Global Biogeochemical Cycles, 11, 235-266, doi:10.1029/97GB00077, 1997.

Horak, R. E. A., Qin, W., Schauer, A. J., Armbrust, E. V., Ingalls, A. E., Moffett, J. W., Stahl, D. A., and Devol, A. H.: Ammonia oxidation kinetics and temperature sensitivity of a natural marine community dominated by Archaea. ISME. 7, 2023-2033, doi:10.1038/ismej.2013.75, 2013.

IOC: Intergovernmental Oceanographic Commission, Paris. Protocols for the Joint Global Flux Study (JGOFS) core measurements. Manuals Guides 29. 1994.

Jiang, M. S., Chai, F., Dugdale, R. C., Wilkerson, F. P., Peng, T. H., and Barber, R. T.: A nitrate and silicate budget in the equatorial Pacific Ocean: a coupled physical-biological model study. Deep-Sea Research Part II 50:29712996, doi:10.1016/j.dsr2.2003.07.006, 2003.

635 Karstensen, J., Stramma, L., and Visbeck, M.: Oxygen minimum zones in the eastern tropical Atlantic and Pacific oceans. Prog. Oceanogr. 77, 331-350, doi:10.1016/j.pocean.2007.05.009, 2008.

Kieber, R. J., Li, A., and Seaton, P. J.: Production of nitrite from the photodegradation of dissolved organic matter in natural waters. Environmental Science and Technology, 33, 993-998, doi:10.1021/es980188a, 1999.

Kiørboe, T.: Turbulence, phytoplankton cell size, and the structure of pelagic food webs. Advances in Marine Biology 29, 2-72, doi:10.1016/S0065-2881(08)60129-7, 1993.

Klass, C., and Archer, D.: Association of sinking organic matter with various types of mineral ballast in the deep sea: Implications for the rain ratio. Global Biogeochemical Cycles 16, 1116, doi:10.1029/2001GB001765, 2002.

Letelier, R. M., Karl, D. M., Abbott, M. R., and Bidigare, R. R.: Light driven seasonal patterns of chlorophyll and nitrate in the lower euphotic zone of the North Pacific Subtropical Gyre. Limnology and Oceanography, 49, 508-519, doi:10.4319/lo.2004.49.2.0508, 2004.

Lomas, M. W., and Lipschultz, F.: Forming the primary nitrite maximum: Nitrifiers or phytoplankton? Limnology and Oceanography, 51, 2453-2467, doi: 10.4319/lo.2006.51.5.2453, 2006. 
Lomas, M. W., Lipschultz, F., Nelson, D. M., Krause, J. W., and Bates, N. R.: Biogeochemical responses to late-winter storms in the Sargasso Sea, I-Pulses of primary and new production. Deep-Sea Research I 56, 843-860, doi:10.1016/j.dsr.2009.01.002, 2009.

Longhurst, A.: Ecological geography of the sea. Academic Press, 1998.

Maranñón, E., Holligan, P. M., Varela, M., Mourinõ, B., Bale, A.J.: Basinscale variability of phytoplankton biomass, production and growth in the Atlantic Ocean. Deep Sea Research I 47, 825-857, doi: 10.1016/S09670637(99)00087-4, 2000.

Martens-Habbena, W., Berube, P. M., Urakawa, H., de la Torre, J. R., and Stahl, D. A.: Ammonia oxidation kinetics determine niche separation of nitrifying Archaea and Bacteria. Nature volume 461, 976-979, doi:10.1038/nature08465, 2009.

McClain, C. R., Signorini, S. R., and Christian, J. R.: Subtropical gyre variability observed by ocean-color satellites. Deep Sea Research Part II: Topical Studies in Oceanography 51, 281-301, doi:10.1016/j.dsr2.2003.08.002, 2004.

McGillicuddy, D. J., Jr, Robinson, A. R., Siegel, D. A., Jannasch, H. W., Johnson, R., Dickey, T. D., McNeil, J., Michaels, A. F., and Knap, A. H.: Influence of mesoscale eddies on new production in the Sargasso Sea, Nature, 394, 263-266, doi:10.1038/28367, 1998.

Meeder, E., Mackey, K. R. M., Paytan, A., Shaked, Y., Iluz, D., Stambler, N., Rivlin, T., Post, A. F., and Lazar, B.: Nitrite dynamics in the open ocean — clues from seasonal and diurnal variations. Mar. Ecol. Prog. Ser. 453, 1126, doi:10.3354/meps09525, 2012.

Mills, M. M., Ridame, C., Davey, M., La Roche, J., and Geider, R. J.: Iron and phosphorus co-limit nitrogen fixation in the eastern tropical North Atlantic. Nature volume 429:292-294, doi:10.1038/nature03632, 2004.

Mitra, A., Flynn, K. J., Burkholder, J. M., Berge, T., Calbet, A., Raven, J. A., Graneli, E., Glibert, P. M., Hansen, P. J., Stoecker, D. K., Thingstad, F., Tillmann, U., Våge, S., Zubkov, M.: The role of mixotrophic protists in the biological carbon pump. Biogeosciences 11, 995-1005, doi:10.5194/bg-11-995-2014, 2014.

Moore, C. M., Mills, M. M., Achterberg, E. P., Geider, R. J., LaRoche, J., Lucas, M. I., McDonagh, E. L., Pan, X., Poulton, A. J., Rijkenberg, M. J. A., Suggett, D. J., Ussher, S. J., and Woodward, E. M. S.: Large-scale distribution of Atlantic nitrogen fixation controlled by iron availability. Nature Geoscience 2, 867-871, doi:10.1038/NGEO667, 2009.

Moore, C. M., Mills, M.M., Arrigo, K. R., Berman-Frank, I., Bopp, L., Boyd, P. W., Galbraith, E. D., Geider, R. J., Guieu, C., Jaccard, S. L., Jickells, T. D., La Roche, J., Lenton, T. M., Mahowald, N. M., Marañón, E., Marinov, I., Moore, J. K., Nakatsuka, T., Oschlies, A., Saito, M. A., Thingstad, T. F., Tsudaand, A., and Ulloa, O.: Processes and patterns of oceanic nutrient limitation. Nat. Geosci. 6, 701-710, doi:10.1038/NGEO1765, 2013.

Moore, J. K., Doney, S. C., Kleypas, J. A., Glover, D. M., and Fung I. Y.: An intermediate complexity marine ecosystem model for the global domain. Deep-Sea Research Part II 49, 403-462, doi:10.1016/S09670645(01)00108-4, 2002.

Mulholland, M. R., Bronk, D. A., and Capone, D. G.: Dinitrogen fixation and release of ammonium and dissolved organic nitrogen by Trichodesmium IMS101, Aquatic Microb. Ecol., 37, 85-94, doi:10.3354/ame037085, 2004.

Mulholland, M. R.: The fate of nitrogen fixed by diazotrophs in the ocean. Biogeosciences. 4, 37-51, doi:10.5194/bg-437-2007, 2007.

Nencioli, F., Dall'Olmo, G.,and Quartly, G. D.: Agulhas ring transport efficiency from combined satellite altimetry and Argo profiles. Journal of Geophysical Research: Oceans, 123. doi:10.1029/2018JC013909, 2018. 
Newell, S. E., Babbin, A. R., Jayakumar, A., and Ward, B. B.: Ammonia oxidation rates and nitrification in the Arabian Sea. Global Biogeochem. Cyc. 25(4):GB4016, doi:10.1029/2010GB003940, 2011.

Newell, S. E., Fawcett, S. E., and Ward, B. B.: Depth distribution of ammonia oxidation rates and ammonia-oxidizer community composition in the Sargasso Sea. Limnol Oceanogr. 58, 491-1500, doi:10.4319/lo.2013.58.4.1491, 2013.

Olson, R. J.: Differential photoinhibition of marine nitrifying bacteria: A possible mechanism for the formation of the primary nitrite maximum. J. Mar. Res. 39, 227-238, doi:10.4319/lo.2006.51.5.2453, 1981.

Oschlies, A., and Garçon, V.: Eddy-induced enhancement of primary production in a model of the North Atlantic Ocean, Nature, 394, 266-269, doi: 10.1038/28373, 1998.

Palinska, K.A., Laloui, W., Bédu, S., Goer, S.L., Castets, A.M., Rippka, R., de Marsac, N.T.: The signal transducer P-II and bicarbonate acquisition in Prochlorococcus marinus PCC 9511, a marine cyanobacterium naturally deficient in nitrate and nitrite assimilation. Microbiology 148, 2405-2412, doi:10.1099/00221287-148-8-2405, 2002.

Partensky, F., Hess, W. R., and Vaulot, D.: Prochlorococcus, a Marine Photosynthetic Prokaryote of Global Significance. Microbiol Mol Biol 63, 06-127, doi:10.1016/j.procbio.2007.09.010, 1999.

Peng, X., Fawcett, S. E., van Oostende, N., Wolf, M. J., Marconi, D., Sigman, D. M., and Ward, B. B.: Nitrogen uptake and nitrification in the subarctic North Atlantic Ocean. Limnol. Oceanogr. 63, 1462-1487, doi:10.1002/lno.10784, 2018

Planas. D., Agusti, S., Duarte, C. M., Granata, T. C., and Merino, M.: Nitrate uptake and diffusive nitrate supply in the Central Atlantic. Limnol. Oceanogr., 44, 116-126, doi:10.4319/lo.1999.44.1.011, 1999.

Polovina, J. J., Howell, E. A., and Abecassis, M.: Ocean's least productive waters are expanding, Geophys. Res. Lett., 35, L03618, doi:10.1029/2007GL031745, 2008.

Poulton, A. J., Holligan, P. M., Hickman, A., Kim, Y-N., Adey, T. R., Stinchcombe, M. C., Holeton, C., Root, S., and Woodward, E. M. S.: Phytoplankton carbon fixation, chlorophyll-biomass and diagnostic pigments in the Atlantic Ocean. Deep-Sea Res. II 53, 1593-1610, doi:10.1016/j.dsr2.2006.05.007, 2006.

Poulton, A. J., Holligan, P. M., Charalampopoulou, A., and Adey, T. R.: Coccolithophore ecology in the tropical and subtropical Atlantic Ocean: new perspectives from the Atlantic meridional transect (AMT) programme. Prog. Oceanogr. 158, 150-170, doi:10.1016/j.pocean.2017.01.003, 2017.

Rafter, P. A., DiFiore, P. J., and Sigman, D. M.: Coupled nitrate nitrogen and oxygen isotopes and organic matter remineralization in the Southern and Pacific Oceans. J. Geophys. Res. 118, 4781-4794, doi:10.1002/jgrc.20316, 2013.

Raes, E. J., van de Kamp, J., Bodrossy, L., Fong, A. A., Riekenberg, J., Holmes, B. H., Erler, D. V., Eyre, B. D., Weil, S-S., and Waite, A. M.: $\mathrm{N}_{2}$ Fixation and New Insights Into Nitrification From the Ice-Edge to the Equator in the South Pacific Ocean. Front. Mar. Sci. 7:389. doi:10.3389/fmars.2020.00389, 2020.

Rees, A. P., Nightingale, P. D., Poulton, A. J., Smyth, T., Tarran, G. A., and Tilstone, G. H.: The Atlantic Meridional Transect programme (1995-2016). Prog. Oceanogr. 158, 3-18, doi:10.1016/j.pocean.2017.05.004, 2017.

Santoro, A. E., Casciotti, K. L., and Francis, C. A.: Activity, abundance and diversity of nitrifying archaea and bacteria in the central California Current, Environ. Microbiol., 12, 1989-2006, doi:10.1111/j.1462-2920.2010.02205.x, 2010.

Santoro, A. E., Buchwald, C., McIlvin, M. R., and Casciotti, K. L.: Isotopic Signature of $\mathrm{N}_{2} \mathrm{O}$ Produced by Marine Ammonia-Oxidizing Archaea. Science 333, 1282-1285, doi:10.1126/science.1208239, 2011. 
Santoro, A. E., Sakamoto, C. M., Smith, J. M. Plant, J. N., Gehman, A. L., Worden, A. Z., Johnson, K. S., Francis, C. A., and Casciotti, K. L.: Measurements of nitrite production in and around the primary nitrite maximum in the central California current. Biogeosciences. 10, 7395-7410, doi:10.5194/bgd-10-5803-2013, 2013.

Sarmiento, J. L., Gruber, N., Brzezinski, M. A. and Dunne, J. P.: High-latitude controls of thermocline nutrients and low latitude biological productivity. Nature 427, 5660, doi:10.1038/nature10605, 2004.

Scharek, R., Tupas, L. M., and Karl, D. M.: Diatom fluxes to the deep sea in the oligotrophic North Pacific gyre at Station ALOHA. Marine Ecology Progress Series 182, 55-67, doi:10.3354/meps182055, 1999.

Shiozaki, T., Ijichi, M., Isobe, K., Hashihama, F., Nakamura, K., Ehama, M., Hayashizaki, K., Takahashi, K., Hamasaki, K., and Furuya, K.: Nitrification and its influence on biogeochemical cycles from the equatorial Pacific to the Arctic Ocean ISME J. 10, 2184-97, doi :10.1038/ismej.2016.18, 2016.

Smith, J. M., Chavez, F. P., and Francis, C. A.: Ammonium Uptake by Phytoplankton Regulates Nitrification in the Sunlit Ocean. PLoS ONE 9:e108173, doi:10.1371/journal.pone.0108173, 2014.

Smith, J. M., Damashek, J., Chavez, F. P., and Francis, C. A.: Factors influencing nitrification rates and the abundance and transcriptional activity of ammonia-oxidizing microorganisms in the dark northeast Pacific Ocean. Limnol. Oceanogr. 61, 596-609, doi:10.1002/lno.10235, 2016.

Somerfield, P. J., and Clarke, K. R.: Inverse analysis in non-parametric multivariate analyses: distinguishing groups of associated species which covary coherently across samples. J. Exp. Mar. Biol. Ecol. 449, 261-273, doi:10.1016/j.jembe.2013.10.002, 2013.

Somerfield, P. J., Clarke, K. R., and Gorley, R. N.: Analysis of Similarities (ANOSIM) for 2-way layouts using a generalised ANOSIM statistic, with comparative notes on Permutational Multivariate Analysis of Variance (PERMANOVA). Austral Ecology, doi:10.1111/aec.13059, 2021.

Taylor, A. H., Harris, J. R. W., and Aiken, J.: The interaction of physical and biological processes in a model of the vertical distribution of phytoplankton under stratification. In: Nihoul, J.C.J. (Ed.), Marine Interfaces Echohydrodynamics. Elsevier Science, Amsterdam, The Netherlands, pp. 313-330, doi:10.1016/S04229894(08)71052-3, 1986.

Tuerena, R. E., Ganeshram, R .S., Geibert, W., Fallick, A. E., Dougans, J., Tait, A., Henley, S. F., and Woodward, E. M. S.: Nutrient cycling in the Atlantic basin: The evolution of nitrate isotope signatures in water masses. Global Biogeochem. Cycles 29, 1830-1844, doi:10.1002/2015GB005164, 2015.

Tuerena, R. E., Williams, R. G., Mahaffey, C., Vic, C., Green, J. A. M., Naveira-Garabato, A., Forryan, A., and Sharples, J.: Internal Tides Drive Nutrient Fluxes Into the Deep Chlorophyll Maximum Over Mid-ocean Ridges. Global Biogeochem. Cyc. 33, 995-1009, doi:10.1029/2019GB006214, 2019.

Vet, W. W. J. M. de; Loosdrecht, M. C. M. van, and Rietveld, L. C.: Phosphorus limitation in nitrifying groundwater filters. Water Research. 46:1061-1069. doi: 10.1016/j.watres.2011.11.075, 2012.

Ussher, S. J., Achterberg, E. P., Powell, C., Baker, A. R., Jickells, T. D., Torres, R., and Worsfold, P. J.: Impact of atmospheric deposition on the contrasting iron biogeochemistry of the North and South Atlantic Ocean. Global Biogeochem. Cycl. 27, 1096-1107, doi:10.1038/s41467-018-03363-0, 2013.

Wang, X. J., Christian, J. R., Murtugudde, R., and Busalacchi, A. J.: Spatial and temporal variability in new production in the equatorial Pacific during 1980-2003: Physical and biogeochemical controls. Deep-Sea Research Part II 53, 677-697, doi:10.1016/j.dsr2.2006.01.023, 2006.

Ward, B. B.: Light and substrate concentration relationships with marine ammonium assimilation and oxidation rates. Mar. Chem. 16, 301-316. doi:10.1016/0304-4203(85)90052-0, 1985. 
https://doi.org/10.5194/bg-2021-184

Preprint. Discussion started: 9 August 2021

(c) Author(s) 2021. CC BY 4.0 License.

Ward, B. B., Glover, H. E., and Lipshultz, F.: Chemoauto-trophic activity and nitrification in the oxygen minimum zone off Peru. Deep-Sea Res. A 36: 1031-1051, doi:10.1016/0198-0149(89)90076-9, 1989.

Ward, B. B.: Nitrification in aquatic systems. In: Capone DA (ed). Encyclopaedia of Environmental Microbiology. Wiley: New York, NY, USA, pp 2144-2167, doi:10.1002/0471263397.env287, 2002.

Zafiriou, O. C., and True, M. B. : Nitrate photolysis in seawater by sunlight. Marine Chemistry, 8, 33-42, doi:10.1016/0304-4203(79)90029-X, 1979.

Zamora, L. M., and Oschlies, A.: Surface nitrification: A major uncertainty in marine $\mathrm{N}_{2} \mathrm{O}$ emissions. Geophys. Res. Lett. 41(12):4247-4253, doi:10.1002/2014GL060556, 2014.

Woodward, E. M. S., and Rees, A. P.: Nutrient distributions in an anticyclonic eddy in the North 490 East Atlantic Ocean, with reference to nanomolar ammonium concentrations. Deep-Sea Res. 491 48(4-5):775-794, doi: 10.1016/S0967-0645(00)00097-7, 2001.

Yool, A., Martin, A. P., Fernández, C., and Clark, D. R.: The significance of nitrification for oceanic new production. Nature 447:999-1002, doi: 10.1038/nature05885, 2007. 


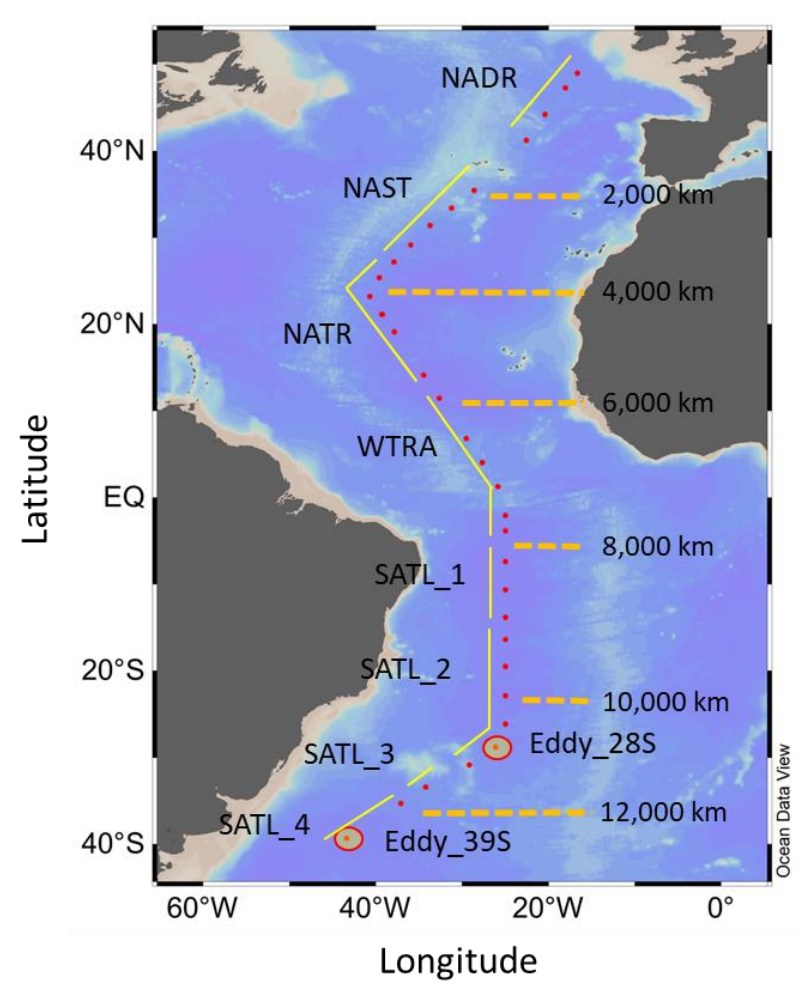

790 Figure 1. Map of the study area, indicating the position of sampling stations for N-cycle studies (red dots), the approximate transect distance and the associated Longhurst provinces (Longhurst, 1998); North Atlantic Drift (NADR), North Atlantic subtropical gyre (NAST), North Atlantic tropical gyre (NATR), Western tropical Atlantic (WTRA), South Atlantic gyre (SATL). The location of two eddy features is also indicated. 

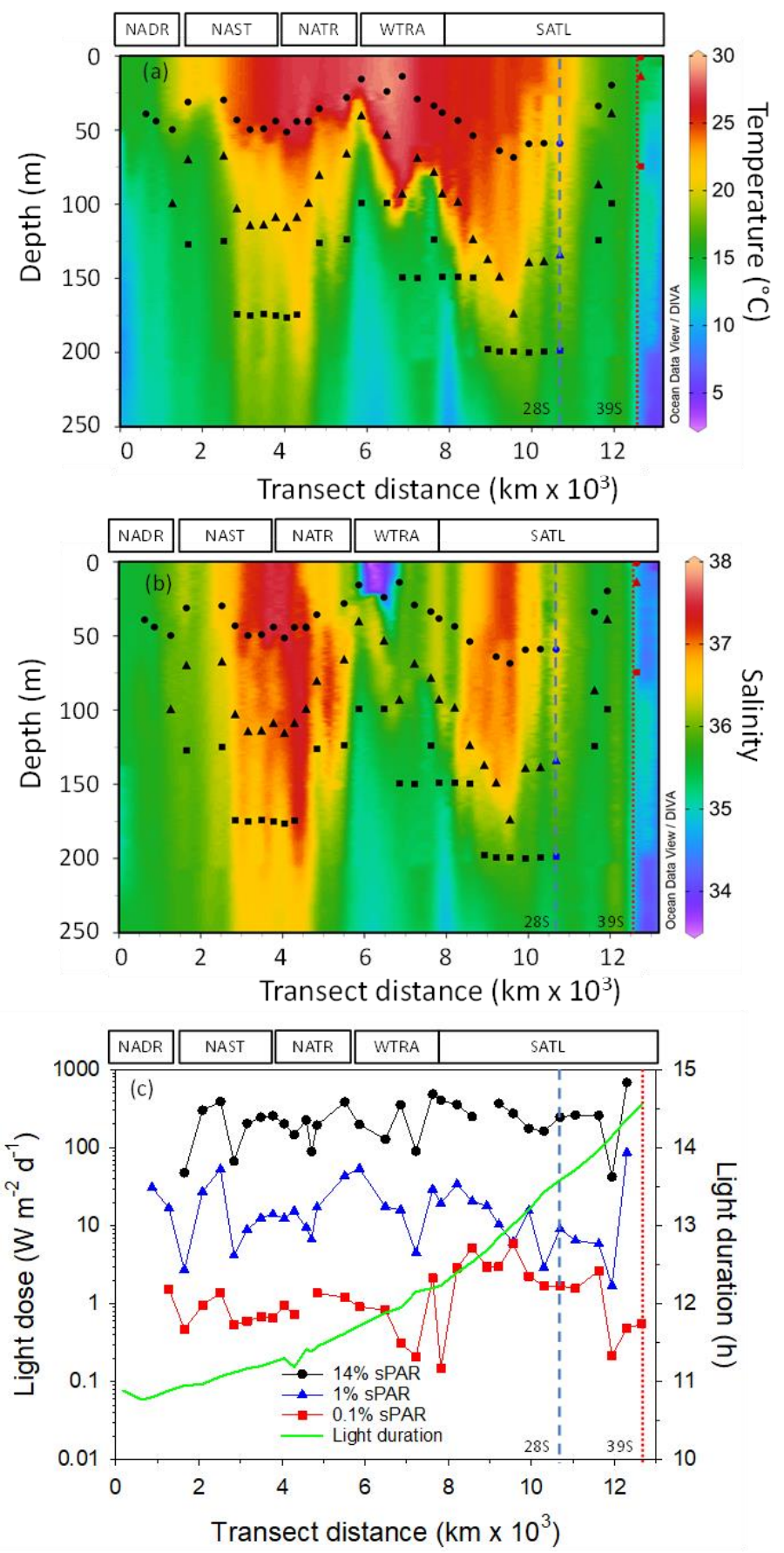

Figure 2. Contour plots of water column temperature (a) and salinity (b) measured during CTD rosette casts. The calculated daily light dose (PAR intensity $x$ light phase duration) received at sampling depths is presented (c), in addition to the duration of the light phase (in hours). The approximate position of Longhurst provinces (defined in Fig. 1 ) is indicated. Symbols represent $14 \%$ sPAR (circle), $1 \%$ sPAR (triangle), $0.1 \%$ sPAR (square). The location of two eddy features is indicated by vertical dashed $\left(28^{\circ} \mathrm{S}\right)$ and dotted $\left(39^{\circ} \mathrm{S}\right)$ lines. 

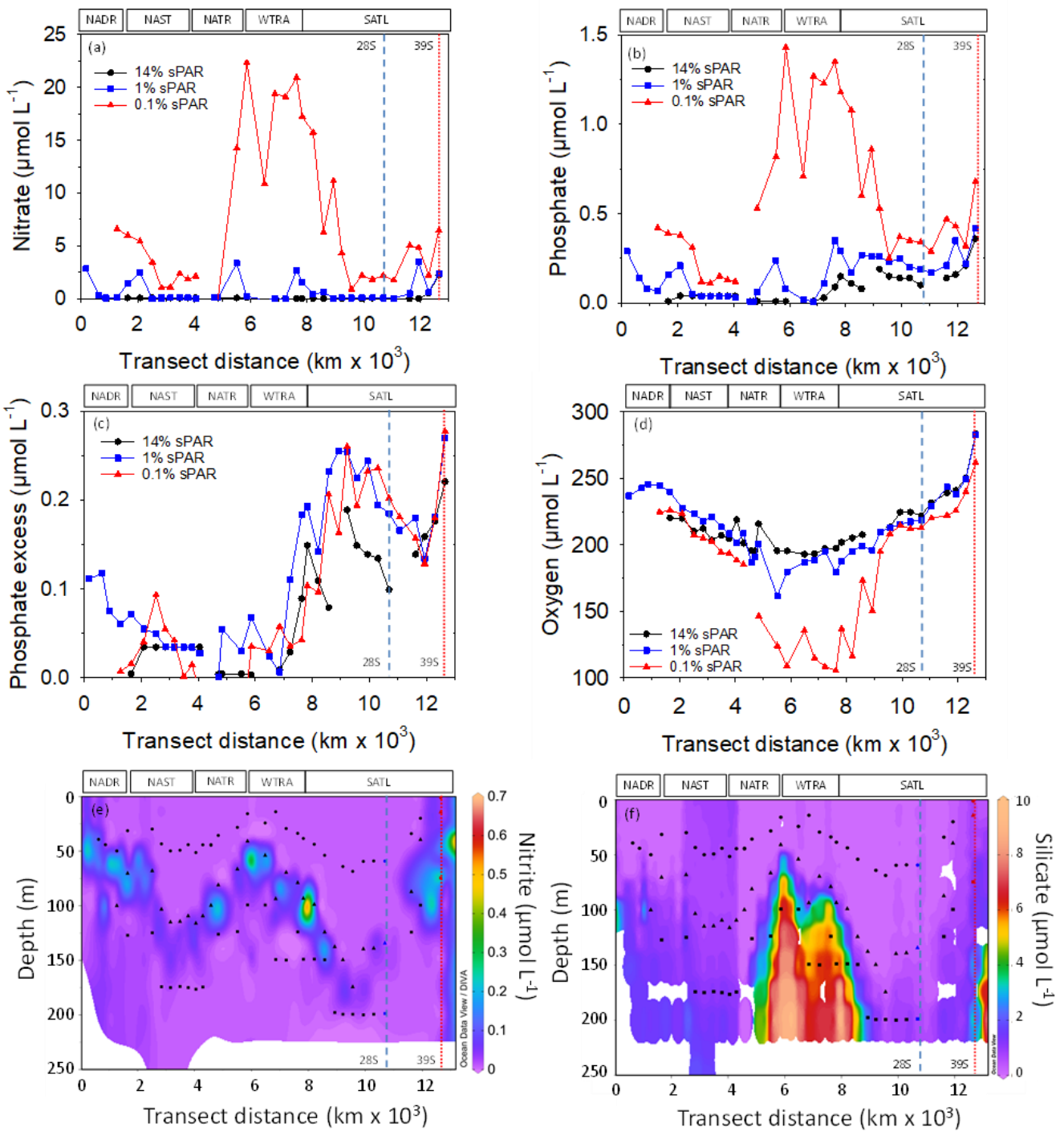

Figure 3. The concentration of nitrate (a), phosphate (b), phosphate excess $\left(\mathrm{P}^{*} ; \mathrm{c}\right)$, oxygen $(\mathrm{d})$, nitrite (e) and silicate (f). The location of two eddy features is indicated by vertical dashed $\left(28^{\circ} \mathrm{S}\right)$ and dotted $\left(39^{\circ} \mathrm{S}\right)$ lines. The approximate location of Longhurst provinces (defined in Fig. 1) is indicated. Symbols represent 14\% sPAR (circle), $1 \%$ sPAR (triangle), $0.1 \%$ sPAR (square). The location of two eddy features is indicated by vertical dashed $\left(28{ }^{\circ} \mathrm{S}\right)$ and dotted $\left(39^{\circ} \mathrm{S}\right)$ lines. 

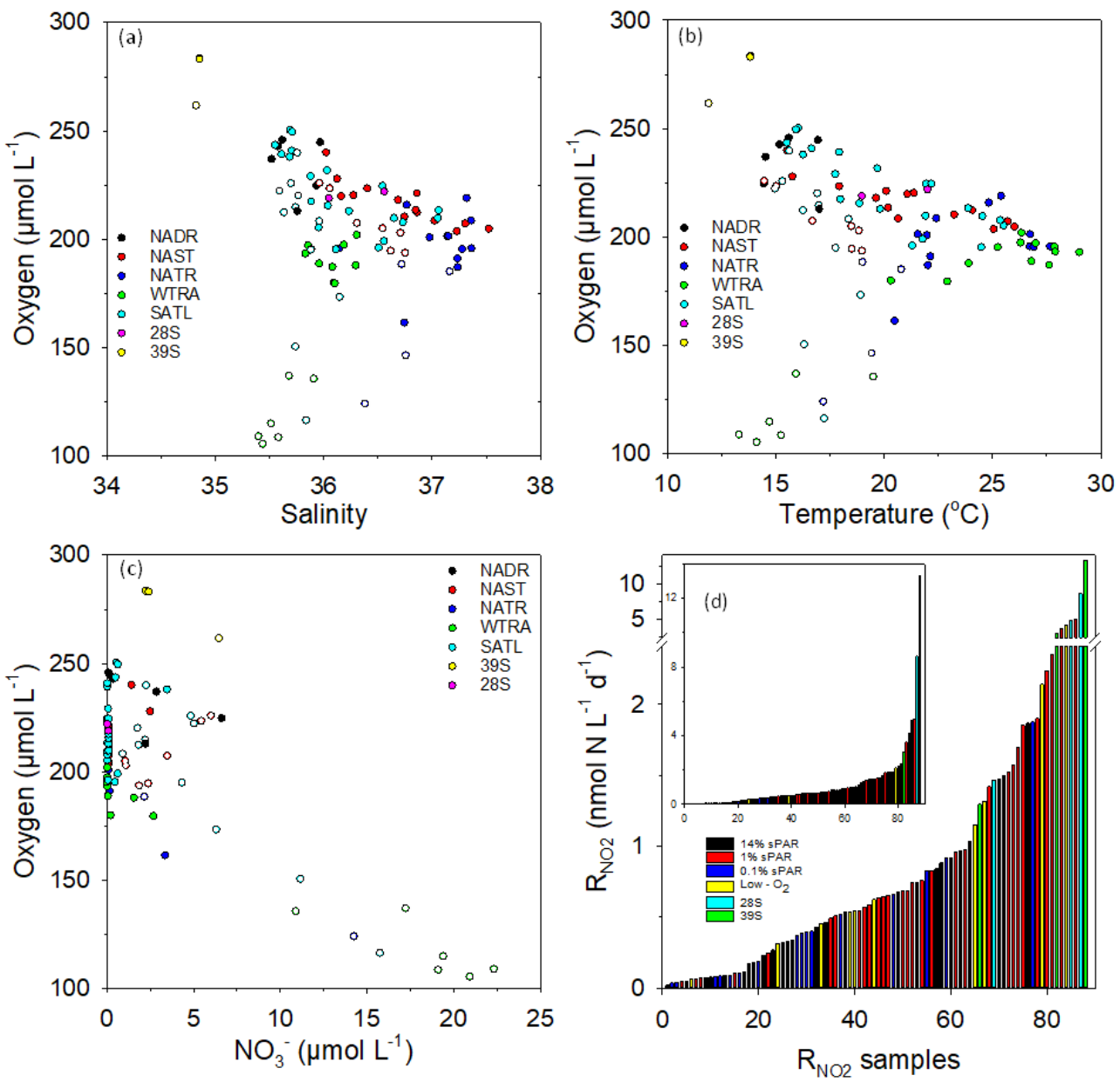

Figure 4. Plots of dissolved oxygen concentration vs salinity (a), temperature (b) and $\mathrm{NO}_{3}{ }^{-}$(c) within Longhurst provinces (defined in Fig. 1). Open circles represent $0.1 \%$ sPAR data, highlighting distinct characteristics associated with specific NATR/WTRA/SATL sampling points. To represent the distribution of rate data, the $88 \mathrm{R}_{\mathrm{NO} 2}$ measurements were arranged in ascending order ( $\mathrm{d}$, insert has linear scale) with an indication of sampling depth, or the association with a specific feature (low oxygen, defined as $<150 \mu \mathrm{mol} \mathrm{L}^{-1}$, or mesoscale eddy). Measurements within eddy features tend towards the high end of the scale, as do measurements at $1 \%$ sPAR. Low oxygen measurements show no clear distributional trend while $14 \%$ and $0.1 \%$ sPAR values tend towards the low end of the scale. 

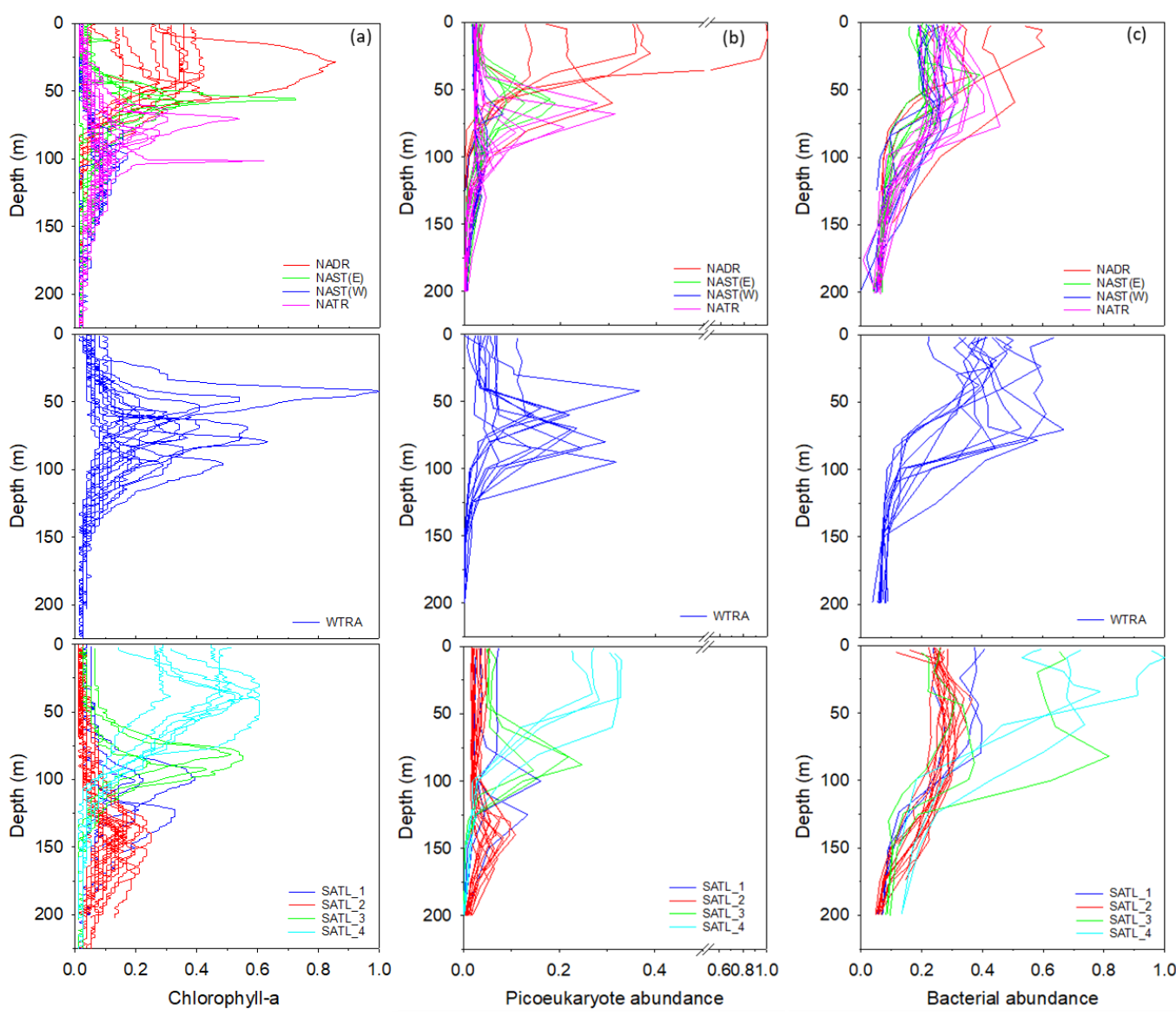

Figure 5. Profiles of chlorophyll-a concentration (a), the abundance of pico-eukaryotes (b) and bacteria (c) within Longhurst provinces (defined in Fig. 1). Data are presented as a ratio of the maximum value measured for each parameter throughout the transect. Profiles frequently describe comparable distributions within a defined province. However, data is sub-divided within the SATL province to illustrate apparent distinctions in vertical structure. 
https://doi.org/10.5194/bg-2021-184

Preprint. Discussion started: 9 August 2021

(c) Author(s) 2021. CC BY 4.0 License.
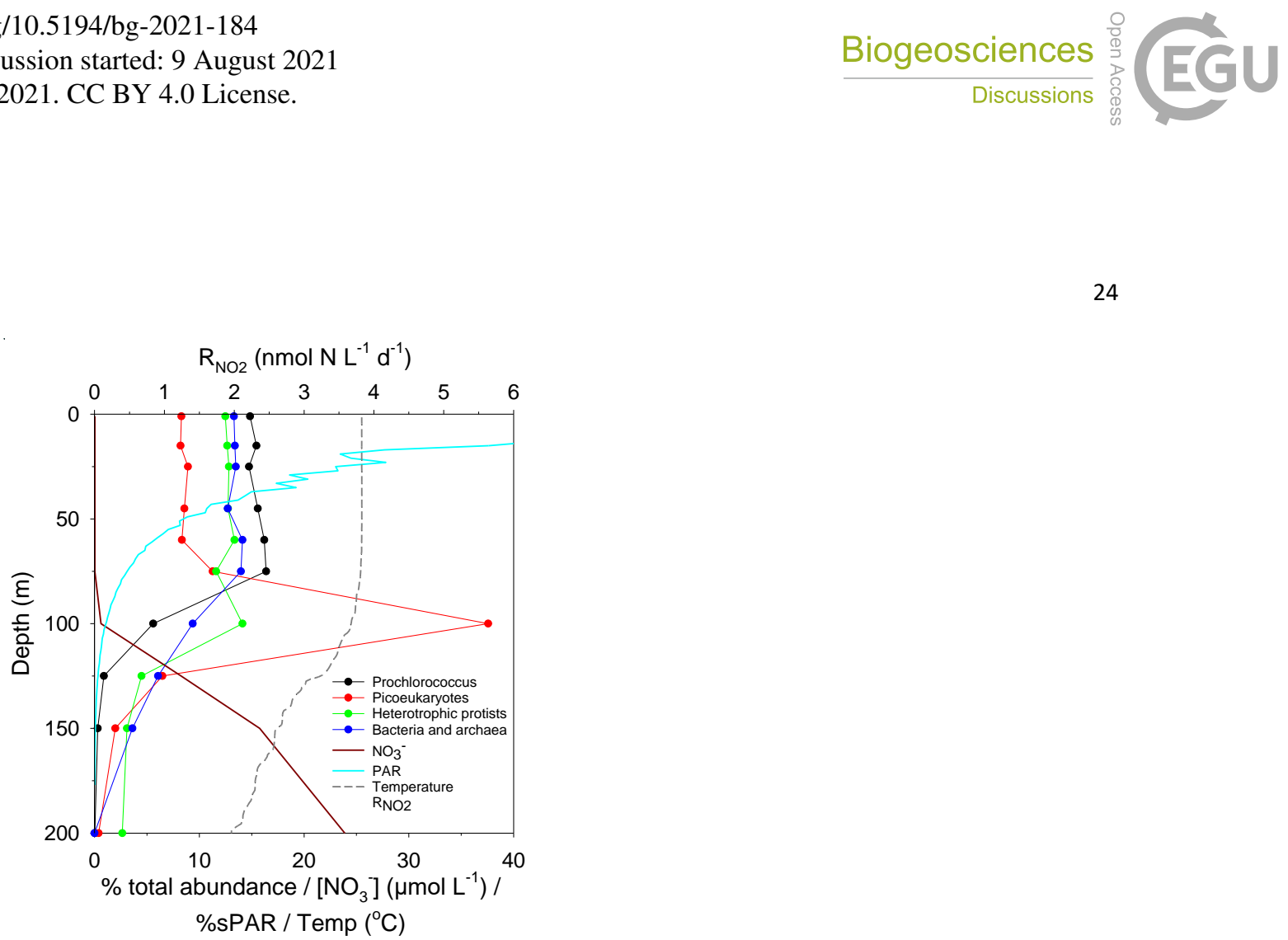

Figure 6. $\mathrm{R}_{\mathrm{NO} 2}$ measurements at $7{ }^{0} \mathrm{~S}$ within the context of selected physical, chemical and biological measurements, illustrating relationships between water column characteristics. 
https://doi.org/10.5194/bg-2021-184

Preprint. Discussion started: 9 August 2021

(c) Author(s) 2021. CC BY 4.0 License.
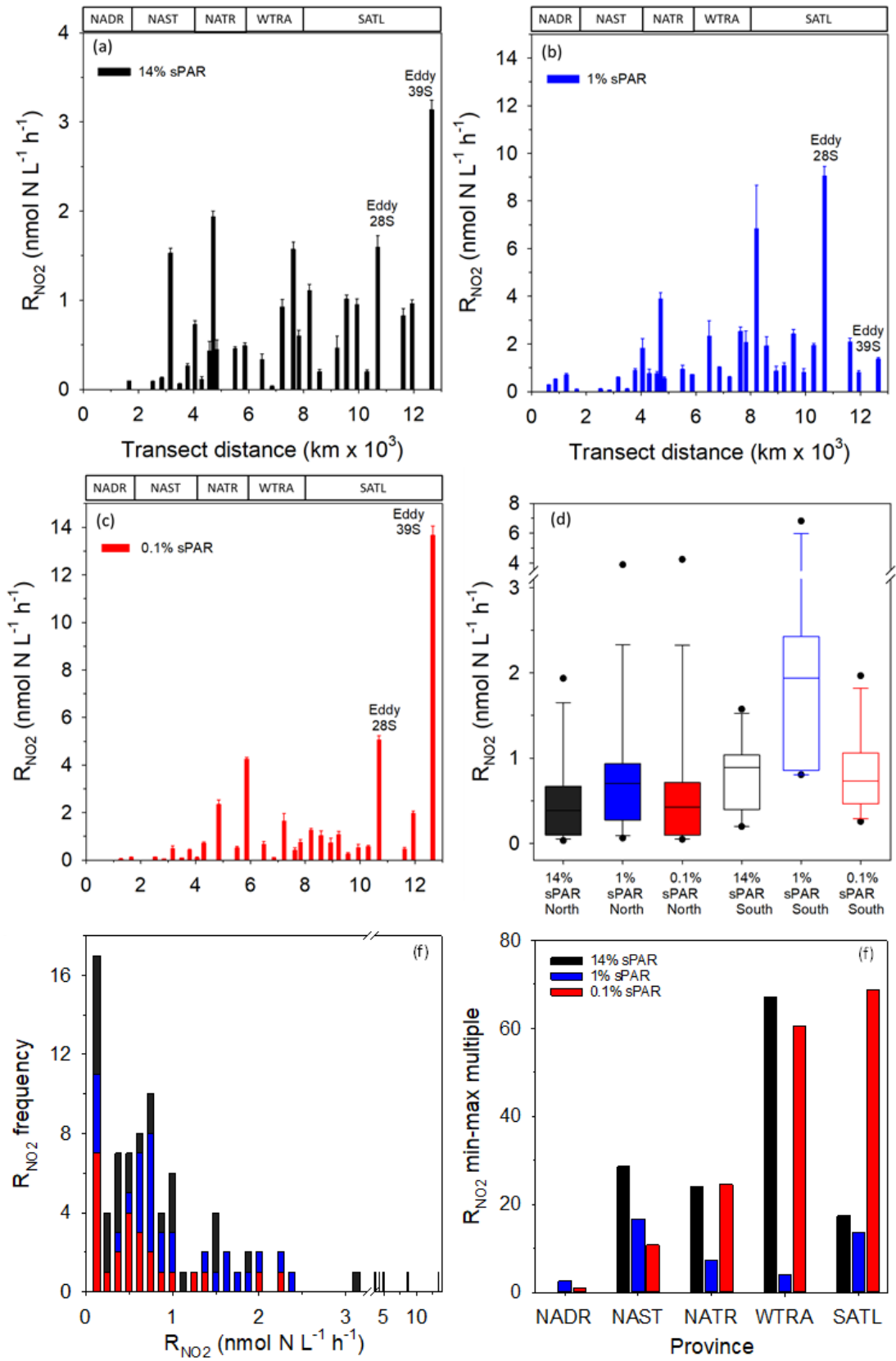

Figure 7. Volumetric rates of $\mathrm{NO}_{2}^{-}$regeneration at $14 \%$ (a), $1 \%$ (b) and $0.1 \%$ (c) sPAR. Error bars represent two standard deviations of triplicate measurements. The approximate position of Longhurst provinces (defined in Fig. 1) is identified in these plots. The box plot (d) presents data for each hemisphere (excluding $28^{\circ} \mathrm{S} / 39^{\circ} \mathrm{S}$ ), as sPAR depths. The 10th, 25th, 75th and 90th data percentiles are presented with data median (line within box). A histogram of the rate distribution and frequency is presented in panel (e). An indication of $\mathrm{R}_{\mathrm{NO} 2}$ variability is presented in panel (f), as the number of minimum value multiples that equate to the largest value within each province. 


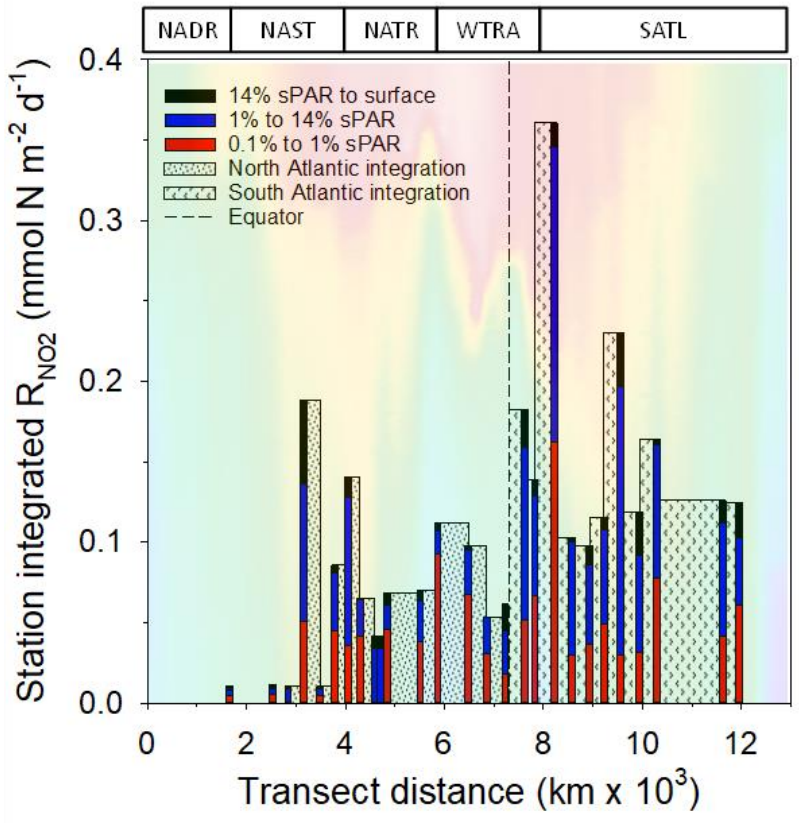

Figure 8. $\mathrm{R}_{\mathrm{NO} 2}$ integrated to the $0.1 \%$ sPAR depth at individual stations. These values (excluding stations $28^{\circ} \mathrm{S}$ and $\left.39^{\circ} \mathrm{S}\right)$ are extrapolated between stations extending from the equator to a comparable distance north $\left(33^{\circ} \mathrm{N}\right)$ and south $\left(35^{\circ} \mathrm{S}\right)$ of the equator. The concentration of ammonium- $\mathrm{N}$ oxidised was calculated to be $0.36 \mathrm{~mol} \mathrm{~N} \mathrm{~d}^{-1}$ over a $1 \mathrm{~m} \mathrm{x}$ $4457 \mathrm{~km}$ distance north of the equator and $0.72 \mathrm{~mol} \mathrm{~N} \mathrm{~d}^{-1}$ over a $1 \mathrm{~m} \mathrm{x} 4637 \mathrm{~km}$ distance south of the equator. Seawater temperature (as presented in Fig. 2) is included to provide illustrative context to the data. The approximate position of Longhurst provinces (defined in Fig. 1) is indicated. 
https://doi.org/10.5194/bg-2021-184

Preprint. Discussion started: 9 August 2021

(c) Author(s) 2021. CC BY 4.0 License.
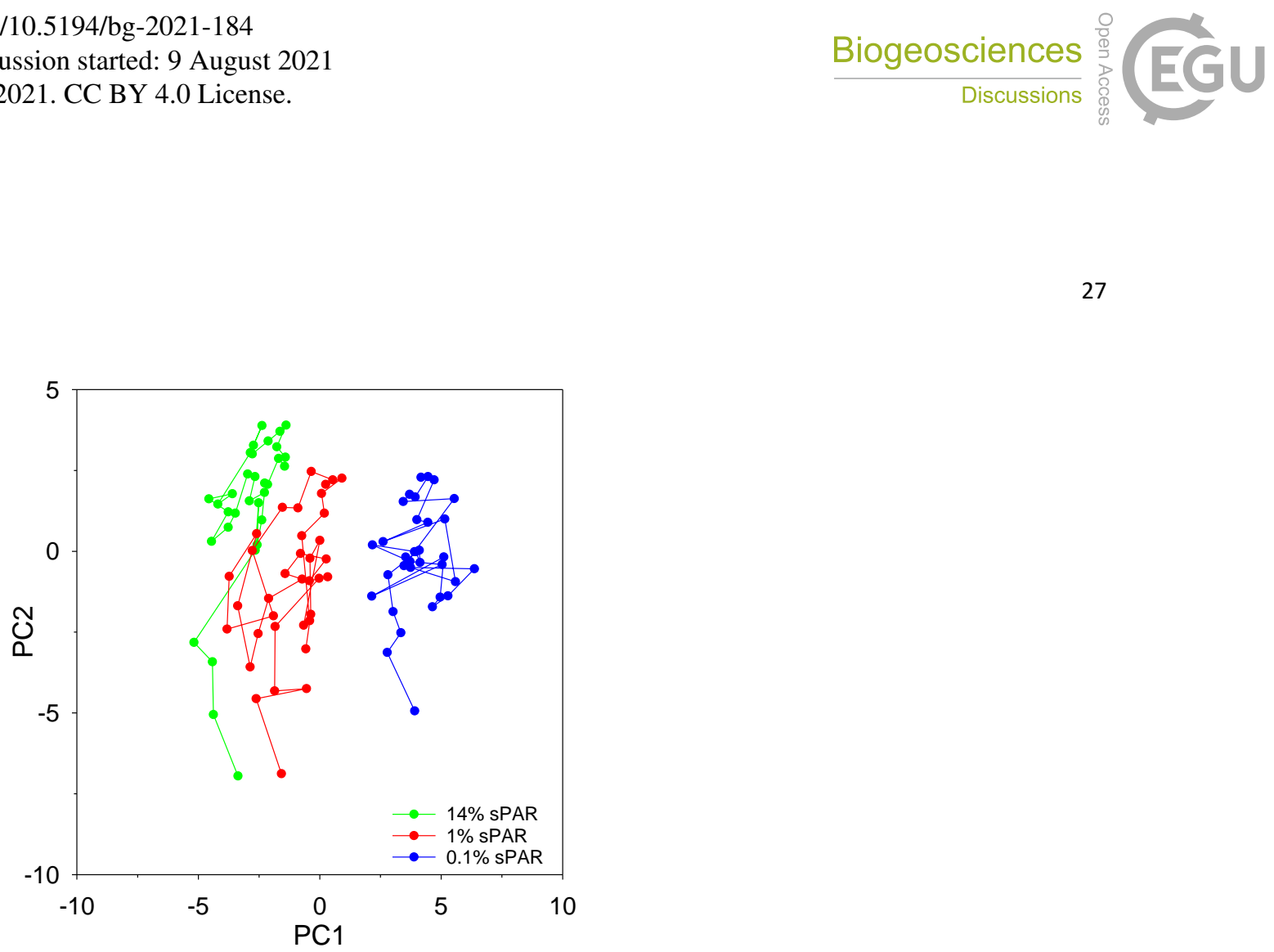

Figure 9. Principle component analysis (PCA) ordination, highlighting the clustering of samples from specific light equivalent depths. PC1, separating the sPAR bands, explained $42.7 \%$ of the total variation while PC2, representing latitudinal variation, explained $23.4 \%$. In combination, $\sim 65 \%$ of variability was explained, leaving $~ 35 \%$ unexplained. 

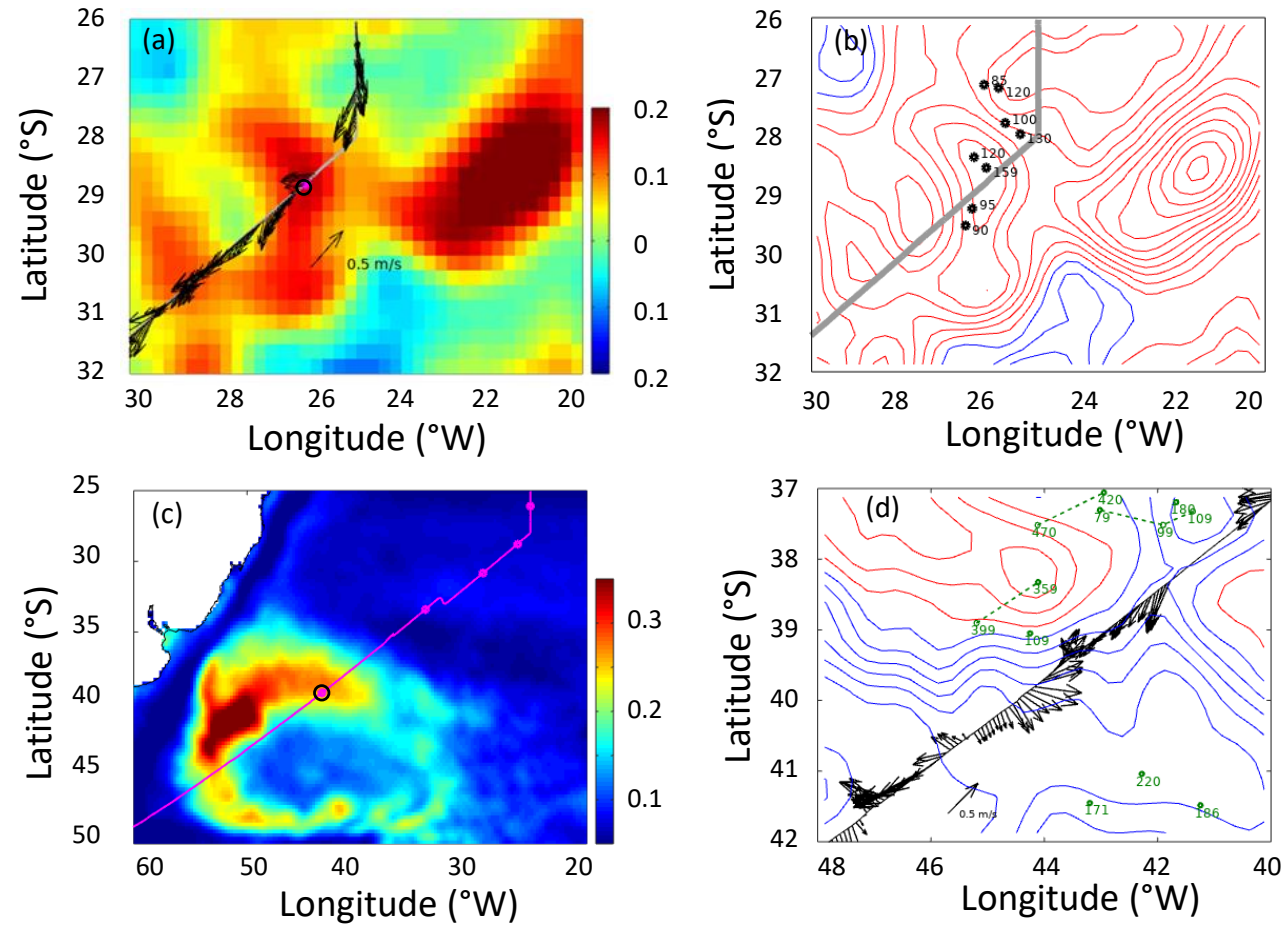

Figure 10. Altimetry, ship and Argo profiler data relating to the two anomalous stations, indicated by magenta dots with black boundaries. a) Sea surface height anomaly (SSHA) at the time of the $28^{\circ} \mathrm{S}$ station. The altimetry shows a high (anticyclone) centred on the station, with a larger feature further east. The arrows provide the currents at $54 \mathrm{~m}$ depth from the shipborne ADCP. b) The same altimetry data as contours (intervals of $0.03 \mathrm{~m}$ ), with dots indicating Argo profiles within 5 days of ship passage, and the numbers being the Mixed Layer Depth (depth at which temperature drops more than $3^{\circ} \mathrm{C}$ below the surface value. c) The root mean square variability in SSHA showing the pattern of large signals associated with the Brazil-Falklands Confluence, and the position of the $39^{\circ} \mathrm{S}$ station. d) Contours of SSH $(0.10$ $\mathrm{m}$ increment, with red for the zero and positive values; blue lines for negative values). The arrows show currents from the shipborne ADCP at $54 \mathrm{~m}$ depth, and the dots and green numbers indicate Argo profiles and MLD within 10 days of ship transit. (Green dashed lines link successive profiles of the same float, with all three being advected eastward). 
https://doi.org/10.5194/bg-2021-184

Preprint. Discussion started: 9 August 2021

(c) Author(s) 2021. CC BY 4.0 License.

Table 1

Results of Principle Components analysis. Eigenvalues are presented in panel (A). In panel (B), Eigenvectors are presented, the coefficients in linear combinations of variables making up principal components (PC).

885

A

\begin{tabular}{llll}
\hline PC & Eigenvalues & \%Variation & Cum.\%Variation \\
\hline 1 & 9.81 & 42.7 & 42.7 \\
2 & 5.38 & 23.4 & 66.1 \\
3 & 1.64 & 7.1 & 73.2 \\
4 & 1.19 & 5.2 & 78.3 \\
5 & 1.16 & 5.1 & 83.4 \\
\hline
\end{tabular}

B

\begin{tabular}{|c|c|c|c|c|c|}
\hline Variable & PC1 & $\mathrm{PC} 2$ & PC3 & PC4 & PC5 \\
\hline $\operatorname{Par}\left(\mu \mathrm{W} \mathrm{cm}^{-2}\right)$ & -0.279 & 0.097 & -0.105 & 0.143 & -0.039 \\
\hline Light (hours) & -0.037 & -0.267 & -0.449 & 0.171 & 0.249 \\
\hline Light $\left(W m^{-2} d^{-1}\right)$ & -0.28 & 0.086 & -0.123 & 0.15 & -0.03 \\
\hline Conductivity $\left(\mathrm{S} \mathrm{m}^{-1}\right)$ & -0.185 & 0.298 & 0.118 & 0.054 & 0.244 \\
\hline Chlorophyll $\left(\mathrm{mg} \mathrm{m}^{-3}\right)$ & -0.056 & -0.288 & 0.258 & -0.04 & 0.332 \\
\hline Dissolved oxygen $\left(\mu \mathrm{mol} \mathrm{L}^{-1}\right)$ & -0.151 & -0.076 & -0.373 & -0.413 & -0.379 \\
\hline Salinity & -0.036 & 0.307 & 0.152 & -0.283 & 0.164 \\
\hline Temperature $\left({ }^{\circ} \mathrm{C}\right)$ & -0.196 & 0.279 & 0.104 & 0.084 & 0.26 \\
\hline $\mathrm{NO}_{2}^{-}\left(\mu \mathrm{mol} \mathrm{L} \mathrm{L}^{-1}\right)$ & -0.003 & -0.252 & 0.263 & -0.466 & -0.136 \\
\hline $\mathrm{NO}_{2}^{-}+\mathrm{NO}_{3}^{-}\left(\mu \mathrm{mol} \mathrm{L}^{-1}\right)$ & 0.259 & -0.165 & 0.162 & 0.138 & -0.034 \\
\hline $\mathrm{NO}_{3}^{-}\left(\mu \mathrm{mol} \mathrm{L}{ }^{-1}\right)$ & 0.244 & -0.169 & 0.223 & 0.2 & -0.103 \\
\hline $\mathrm{PO}_{4}{ }^{3-}\left(\mu \mathrm{mol} \mathrm{L}^{-1}\right)$ & 0.203 & -0.243 & -0.072 & 0.122 & 0.266 \\
\hline $\mathrm{Si}\left(\mu \mathrm{mol} \mathrm{L}{ }^{-1}\right)$ & 0.236 & -0.066 & 0.165 & 0.254 & -0.047 \\
\hline $\mathrm{P}^{*}\left(\mu \mathrm{mol} \mathrm{L} \mathrm{L}^{-1}\right)$ & 0.013 & -0.221 & -0.398 & -0.232 & 0.499 \\
\hline Synechococcus $\left(\right.$ cell $\left.\mathrm{mL}^{-1}\right)$ & -0.255 & -0.152 & -0.046 & 0.227 & -0.26 \\
\hline Prochlorococcus $\left(\right.$ cell $\mathrm{mL}^{-1}$ ) & -0.25 & 0.146 & 0.206 & -0.09 & 0.166 \\
\hline Pico-eukaryote $\left(<2 \mu \mathrm{m}\right.$; cell $\left.\mathrm{mL}^{-1}\right)$ & -0.231 & -0.197 & 0.24 & -0.247 & 0.067 \\
\hline Nano-eukaryote $\left(2-12 \mu \mathrm{m}\right.$; cell $\left.\mathrm{mL}^{-1}\right)$ & -0.261 & -0.2 & 0.027 & 0.008 & 0.075 \\
\hline Coccolithophores (cell mL $\mathrm{mL}^{-1}$ ) & -0.205 & -0.174 & 0.194 & 0.149 & 0.19 \\
\hline Cryptophytes (cell mL $\mathrm{mL}^{-1}$ ) & -0.089 & -0.311 & 0.191 & -0.184 & -0.022 \\
\hline Low nucleic acid bacteria (cell $\mathrm{mL}^{-1}$ ) & -0.279 & -0.14 & 0.015 & 0.158 & -0.124 \\
\hline High nucleic acid bacteria (cell $\mathrm{mL}^{-1}$ ) & -0.292 & -0.099 & 0.043 & 0.187 & -0.083 \\
\hline Heterotrophic protists (cell $\mathrm{mL}^{-1}$ ) & -0.239 & -0.226 & 0.057 & 0.143 & -0.107 \\
\hline
\end{tabular}

